Linköping Studies in Science and Technology

Dissertation No. 1670

\title{
Electron Paramagnetic Resonance Studies of Point Defects in AlGaN and $\mathrm{SiC}$
}

Xuan Thang Trinh

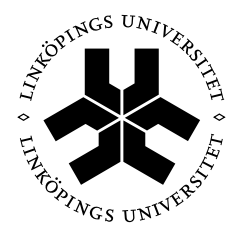

\section{Linköping University} INSTITUTE OF TECHNOLOGY

Semiconductor Materials Division

Department of Physics, Chemistry and Biology (IFM)

Linköping universitet

SE-581 83 Linköping, Sweden

Linköping 2015 
(C) Xuan Thang Trinh 2015

Printed in Sweden by LiU-Tryck 2015

ISSN 0345-7524

ISBN 978-91-7519-064-8 


\section{ABSTRACT}

Point defects in semiconductor materials are known to have important influence on the performance of electronic devices. For defect control, knowledge on the model of defects and their properties is required. Information on defects, such as the symmetry and the localization of spins, is essential for identification of defects and understanding their electronic structure. Such information can be obtained from Electron Paramagnetic Resonance (EPR). In many cases, the energy levels of defects can be determined from photoexcitation EPR (photo-EPR) or temperature dependence of the EPR signal. The thesis contains six papers, focusing on the identification and electronic structure investigation of defects and impurities in $\mathrm{Al}_{\mathrm{x}} \mathrm{Ga}_{1-\mathrm{x}} \mathrm{N}(\mathrm{x} \sim 0.7-1)$ and silicon carbide $(\mathrm{SiC})$ using EPR in combination with other electrical characterizations and density functional theory calculations.

The two first papers concern EPR studies of silicon $(\mathrm{Si})$ in AlGaN alloys. Due to its direct and wide band gap which can be tailored from $3.4 \mathrm{eV}$ for $\mathrm{GaN}$ to $6.2 \mathrm{eV}$ for $\mathrm{AlN}$, high-Al-content wurtzite $\mathrm{Al}_{\mathrm{x}} \mathrm{Ga}_{1-\mathrm{x}} \mathrm{N}(\mathrm{x} \geq 0.7)$ has been considered as a promising material for fabrication of compact, highefficiency and non-toxic deep ultraviolet light-emitting diodes (LEDs) and laser diodes (LDs) for replacing low-efficiency and toxic mercury lamps in water/air purification and sterilization. Si is commonly used for $n$-type doping in $\mathrm{AlGaN}$ and $\mathrm{AlN}$, but the conductivity of Si-doped $\mathrm{Al}_{\mathrm{x}} \mathrm{Ga}_{1-\mathrm{x}} \mathrm{N}$ was often reported to drop abruptly at high $\mathrm{Al}$ content $(\mathrm{x}>0.7)$ and the reason was often speculated to be due to either carrier compensation by other deep levels or $\mathrm{Si}$ itself when it transforms from a shallow donor to a DX (or negative-U) center which acts as an acceptor. In paper 1, we showed that $\mathrm{Si}$ already forms a stable DX center in $\mathrm{Al}_{\mathrm{x}} \mathrm{Ga}_{1-\mathrm{x}} \mathrm{N}$ with $\mathrm{x} \sim 0.77$. However, with the Fermi level locating only $\sim 3 \mathrm{meV}$ below the neutral charge state, $\mathrm{E}_{\mathrm{d}}$, Si still behaves as a shallow donor. Negligible carrier compensation by oxygen $(\mathrm{O})$ in $\mathrm{Al}_{0.77} \mathrm{Ga}_{0.23} \mathrm{~N}: \mathrm{Si}$ layers was observed, suggesting that at such $\mathrm{Al}$ content, $\mathrm{O}$ does not seem to hinder the $n$-type doping in the material. In paper 2, we found the coexistence of two Si DX centers, the stable DX1 and the metastable DX2, in $\mathrm{Al}_{\mathrm{x}} \mathrm{Ga}_{1-\mathrm{x}} \mathrm{N}$ for $\mathrm{x} \geq 0.84$. For the stable DX1 center, abrupt deepening of the energy level of the negative charge state $\mathrm{DX}^{-}, \mathrm{E}_{\mathrm{DX}}$, which determines the ionization energy $\mathrm{E}_{\mathrm{a}}$ of the Si donor, with increasing of the $\mathrm{Al}$ content for $\mathrm{x} \geq 0.83$ was observed. The dependence of $\mathrm{E}_{\mathrm{a}}$ on the $\mathrm{Al}$ content in $\mathrm{Al}_{\mathrm{x}} \mathrm{Ga}_{1-\mathrm{x}} \mathrm{N}$ :Si layers $(0.79 \leq \mathrm{x} \leq 1)$ was determined. The results explain the drastic decrease of the conductivity as often reported for $\mathrm{Al}_{x} \mathrm{Ga}_{1-\mathrm{x}} \mathrm{N}: \mathrm{Si}$ in previous transport studies. For the metastable DX2 center, we found that the $\mathrm{E}_{\mathrm{DX}}$ level remains close to $\mathrm{E}_{\mathrm{d}}$ for $\mathrm{x}=0.84 \div 1$.

$\mathrm{SiC}$ is a wide band-gap semiconductor having high-thermal conductivity, high breakdown field, and large saturated electron drift velocity which are 
essential properties for high-voltage and high-power devices. In paper 3, the identification of niobium $(\mathrm{Nb})$ in $4 \mathrm{H}-$ and $6 \mathrm{H}-\mathrm{SiC}$ grown by high-temperature chemical vapor deposition (CVD) by EPR and theoretical calculations is presented. We showed that the incorporated $\mathrm{Nb}$ formed asymmetric split-vacancy defect $\left(\mathrm{Nb}_{\mathrm{Si}} \mathrm{V}_{\mathrm{C}}\right)$ in which $\mathrm{Nb}$ locates in a divacancy, closer to the Si vacancy, and prefers only the hexagonal-hexagonal configuration. In papers $\mathbf{4}$ and $\mathbf{5}$, we present the identification and the electronic structure of the negative- $U$ $\mathrm{Z}_{1} / \mathrm{Z}_{2}$ center in $4 \mathrm{H}-\mathrm{SiC}$. The $\mathrm{Z}_{1} / \mathrm{Z}_{2}$ defect is known to be the most common deep level revealed by Deep Level Transient Spectroscopy (DLTS) in 4H-SiC epitaxial layers grown by CVD. The center is also known to be the lifetime killer in as-grown CVD material and, therefore, attracts much attention. Using high-doped $n$-type free-standing $4 \mathrm{H}$-SiC layers irradiated with low-energy $(250 \mathrm{keV})$ electrons, which mainly displace carbon atoms creating $\mathrm{C}$ vacancies $\left(\mathrm{V}_{\mathrm{C}}\right), \mathrm{C}$ interstitials and their associated defects, it was possible to increase the irradiation dose and, hence, the defect concentration, allowing the application of EPR and DLTS on the same samples. In paper 4, using EPR, photo-EPR, DLTS and capacitance-voltage measurements, we showed that the $Z_{1} / Z_{2}$ center is related to the (2-|0) level of $V_{C}$ and its higher-lying levels $Z_{1}$ and $Z_{2}$ are related to the $(-\mid 0)$ levels of $\mathrm{V}_{\mathrm{C}}$ at the hexagonal $(h)$ and quasi-cubic $(k)$ sites, respectively. In paper 5, combining EPR and supercell calculations, the negatively charged $\mathrm{V}_{\mathrm{C}}$ at the $k$-site was identified. We obtained the excellent agreement in the energy levels of $Z_{1} / Z_{2}$ determined by DLTS and energy levels of $V_{C}$ calculated by supercell calculations and observed clear negative-U behaviors of the negatively charged $\mathrm{V}_{\mathrm{C}}$ at both $k$ and $h$-sites by EPR measurements, consolidating our assignment of the $Z_{1} / Z_{2}$ levels to the negatively charged states of $\mathrm{V}_{\mathrm{C}}$. In paper $\mathbf{6}$, we studied a defect related to displaced $\mathrm{C}$ atoms in $n$-type $4 \mathrm{H}$-SiC irradiated by low-energy electrons. In irradiated layers, we observed an EPR center at room temperature. After annealing at temperatures in the range of $300-500{ }^{\circ} \mathrm{C}$, this center transforms to a second configuration which is observed in darkness and can be changed back to the first configuration under illumination. Based on the observed ${ }^{29} \mathrm{Si}$ and ${ }^{13} \mathrm{C}$ hyperfine structures, two observed configurations of the EPR center were suggested to be related to different configurations of a carbon interstitial cluster. The annealing, bistable behaviors and energy levels of this EPR center are discussed. 


\section{Populärvetenskaplig sammanfattning}

Punktdefekter i halvledarmaterial är kända för att ha en stor inverkan på elektroniska komponenters funktionalitet. För att kunna kontrollera dessa defekter, krävs kunskap om defekternas egenskaper. Information om defekters egenskaper, såsom symmetri och lokalisering av spinn, är avgörande för att kunna identifiera defekter och förstå deras elektroniska struktur. Sådan information kan erhållas från Elektronspinnresonans (EPR). I många fall kan energinivåerna för defekter bestämmas från EPR med fotoexcitation eller genom att studera EPR signalens temperaturberoende. Denna avhandling innehåller sex vetenskapliga artiklar som fokuserar på identifiering och bestämning av elektroniska strukturer hos defekter och föroreningar i $\mathrm{Al}_{\mathrm{x}} \mathrm{Ga}_{1-\mathrm{x}} \mathrm{N}(\mathrm{x} \sim 0.7-1)$ och kiselkarbid ( $\mathrm{SiC})$ genom att använda EPR i kombination med elektrisk karaktärisering och teoretiska beräkningar.

I de två första artiklarna har kisel ( $\mathrm{Si})$ dopad $\mathrm{AlGaN}$ legeringar studerats med EPR. På grund av dess direkta och breda bandgap, som kan skräddarsys från $3.4 \mathrm{eV}$ för $\mathrm{GaN}$ till $6.2 \mathrm{eV}$ för $\mathrm{AlN}$, har $\mathrm{Al}_{\mathrm{x}} \mathrm{Ga}_{1-\mathrm{x}} \mathrm{N}$ med högt $\mathrm{Al}$ innehåll $(\mathrm{x} \geq 0.7)$ ansetts som ett lovande material för tillverkning av kompakta högeffektiva djup ultraviolett emitterande lysdioder eller laserdioder, för att ersätta lågeffektiva och giftiga kvicksilverlampor för vattenrening, luftrening och sterilisering. Si används ofta för $n$-typ dopning av $\mathrm{AlGaN}$ och $\mathrm{AlN}$, men ledningsförmågan hos Si-dopad $\mathrm{Al}_{\mathrm{x}} \mathrm{Ga}_{1-\mathrm{x}} \mathrm{N}$ minskar abrupt vid höga $\mathrm{Al}$-halter $(x>0.7)$ och anledningen har spekulerats bero på antingen formation av defekter med djupa defekt nivåer som infångar fria elektroner eller av Si själv som omvandlas från en grund donator till ett så kallat DX-center (eller negativ-U) som beter sig som en acceptor. I vår studie har EPR används för att klargöra om det negativa- $U$ beteendet av $\mathrm{Si}$ vid höga Al-halter $(\mathrm{x} \geq 0.7)$. Vi har visat att Si bildar ett stabilt $\mathrm{DX}$-center redan i $\mathrm{Al}_{\mathrm{x}} \mathrm{Ga}_{1-\mathrm{x}} \mathrm{N}$ med $\mathrm{x} \sim 0.77$ men det fortfarande beter sig som en grund donator med Al-halter upp till $\mathrm{x} \sim 0.83$. För $\mathrm{x} \geq 0.84$, fann vi att två Si DX-center samexisterar och bildar en stabil DX1 och metastabil DX2 tillstånd i $\mathrm{Al}_{\mathrm{x}} \mathrm{Ga}_{1-\mathrm{x}} \mathrm{N}$. Den stabila DX1 tillståndet förklarar den drastiska minskningen av ledningsförmågan som rapporterats för $\mathrm{Al}_{\mathrm{x}} \mathrm{Ga}_{1-\mathrm{x}} \mathrm{N}: \mathrm{Si}$ i tidigare studier. För det metastabila DX2 tillståndet, ligger energinivån hos det negativa laddningstillståndet $\mathrm{DX}^{-}$nära det neutrala laddningstillståndet även för AlN.

$\mathrm{SiC}$ är en halvledare som har ett stort bandgap och som har en hög värmeledningsförmåga, genombrottsfälts styrka, och drifthastighet, vilket är nödvändiga materialegenskaper för att kunna tillverka effektiva elektroniska högspänning- och högeffektkomponenter. För bipolära högspänningskomponenter, så som PiN dioder, bipolära transistorer och tyristorer, som arbetar vid höga injektionsförhållanden, kan effektförlusterna reduceras genom så kallad kon- 
duktivitetsmodulering vilket kräver långa laddningsbärarlivstider för att fungera effektivt. Laddningsbärarlivstiden för $4 \mathrm{H}-\mathrm{SiC}$ begränsas av defekten $\mathrm{Z}_{1} / \mathrm{Z}_{2}$ vilken är den vanligaste djupa defektnivån i epitaxiella skikt odlade med chemical vapor deposition (CVD), enligt undersökningar med deep level transient spectroscopy (DLTS). Trots två årtionden av intensiva studier, inklusive teoretiska beräkningar och olika experimentella undersökningar är ursprunget av $Z_{1} / Z_{2}$ defekten fortfarande oklart. Genom att använda hög $n$-typ dopad $4 \mathrm{H}-\mathrm{SiC}$ skikt och bestråla dem med lågenergielektroner $(250 \mathrm{keV})$, vilket huvudsakligen påverkar kolatomernas positioner i kristallen och skapar kolvakanser $\left(\mathrm{V}_{\mathrm{C}}\right)$, interstitiella kolatomer och andra relaterade defekter, var det möjligt att öka koncentrationen av $V_{C}$ i materialet vilket möjliggör EPR mätningar medan $n$-typ konduktiviteten bibehölls tillräckligt hög för att kunna observera $Z_{1} / Z_{2}$ defekterna med DLTS och på så sätt direkt korrelera resultaten från de två metoderna. Genom att kombinera EPR, DLTS, kapacitansspännings mätningar och teoretiskaberäkningar, kunde vi identifiera den negativt laddade $\mathrm{V}_{\mathrm{C}}$ på kvasi-kubisk kristallposition och kunde på så sätt visa att ursprunget till det negativa- $U Z_{1} / Z_{2}$ centret är relaterat till $V_{C}$ i enkelt och dubbelt negativt laddningstillstånd. Vi fann även att interstitiella kolatomer med metastabila egenskaper och hög termisk stablitet jämfört med kända splitinterstitiella kolatomer kunde skapas i lågenergielektron bestrålade prov. EPR och DLTS studierna indikerar att defekten är en djup elektronfälla. Genom att kombinera EPR med teoretiska beräkningar identifierade vi niob $(\mathrm{Nb})$ föroreningar i $4 \mathrm{H}-$ och $6 \mathrm{H}-\mathrm{SiC}$ och visade att övergångsmetallen $\mathrm{Nb}$ föredrar att forma en asymmetrisk splitvakans där $\mathrm{Nb}$ ligger i en divakans men dess position ligger något närmare kiselvakansen. Den asymmetriska splitvakansen formas lättare på den hexagonala kristallpositionen där Si-C bindningen är horisontellt spegelsymmetrisk. Därför kunde endast den hexagonala-hexagonala konfigurationen bli identifierad i $4 \mathrm{H}-$ and $6 \mathrm{H}-\mathrm{SiC}$. 


\section{Papers included in the thesis}

\section{Negative-U behavior of the $\mathrm{Si}$ donor in $\mathrm{Al}_{\mathbf{0 . 7 7}} \mathbf{G a}_{0.23} \mathrm{~N}$}

$\underline{X}$. T. Trinh, D. Nilsson, I. G. Ivanov, E. Janzén, A. KakanakovaGeorgieva, and N. T. Son.

Applied Physics Letters 103, 042101 (2013)

2. Stable and metastable Si negative-U centers in AIGaN and AIN

X. T. Trinh, D. Nilsson, I. G. Ivanov, E. Janzén, A. KakanakovaGeorgieva, and N. T. Son.

Applied Physics Letters 105, 162106 (2014)

3. Electron paramagnetic resonance and theoretical studies of $\mathrm{Nb}$ in 4H- and $6 \mathrm{H}-\mathrm{SiC}$

N. T. Son, X. T. Trinh, A. Gällström, S. Leone, O. Kordina, E. Janzén, K. Szász, V. Ivády, and A. Gali.

Journal of Applied Physics 112, 083711 (2012)

4. Negative- $U$ System of Carbon Vacancy in $4 H-S i C$

N. T. Son, X. T. Trinh, L. S. Løvlie, B. G. Svensson, K. Kawahara, J. Suda, T. Kimoto, T. Umeda, J. Isoya, T. Makino, T. Ohshima, and E. Janzén

Physical Review Letters 109, 187603 (2012)

5. Negative- $U$ carbon vacancy in $4 \mathrm{H}$-SiC: Assessment of charge correction schemes and identification of the negative carbon vacancy at the quasicubic site

X. T. Trinh, K. Szász, T. Hornos, K. Kawahara, J. Suda, T. Kimoto, A. Gali, E. Janzén, and N. T. Son

Physical Review B 88, 235209 (2013)

6. Electron paramagnetic resonance studies of carbon interstitial related defects in $\mathbf{4 H}$-SiC

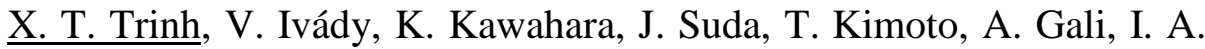
Abrikosov, E. Janzén and N. T. Son

Manuscript 


\section{My contribution to the papers}

Paper 1. I performed most of the EPR experiments, participated in analysis of the data and took part in writing of the manuscript.

Paper 2. I performed the EPR experiments, analyzed the data and wrote the first draft. The paper was then finalized with help of other coauthors.

Paper 3. I took part in the EPR experiments, participated in the analysis of the EPR data and discussion of the results and in writing of the manuscript.

Paper 4. I performed most of the EPR experiments, participated in the analysis of the EPR data and discussion of the results.

Paper 5. I performed the EPR experiments, analyzed the data and wrote the parts related to EPR of the first draft. The paper was then finalized with help of other co-authors.

Paper 6. I planned and performed the EPR experiments, analyzed the data and wrote the first draft of the manuscript. 
Publications not included in the thesis

\section{Journal Articles}

1. Investigation on origin of $\mathrm{Z}_{1 / 2}$ center in $\mathrm{SiC}$ by deep level transient spectroscopy and electron paramagnetic resonance

K. Kawahara, X. T. Trinh, N. T. Son, E. Janzén, J. Suda and T. Kimoto Applied Physics Letters 102, 112106 (2013)

2. The complex impact of silicon and oxygen on the n-type conductivity of high-Al-content AlGaN

A. Kakanakova-Georgieva, D. Nilsson, X. T. Trinh, U. Forsberg, N. T. Son, and Erik Janzén

Applied Physics Letters 102, 132113 (2013)

3. Theoretical and electron paramagnetic resonance studies of hyperfine interaction in nitrogen doped $4 \mathrm{H}$ and $6 \mathrm{H} \mathrm{SiC}$

K. Szász, X. T. Trinh, N. T. Son, E. Janzén and A. Gali.

Journal of Applied Physics 115, 073705 (2014)

4. Quantitative comparison between $Z_{1 / 2}$ center and carbon vacancy in $\mathbf{4 H}-\mathrm{SiC}$

K. Kawahara, X. T. Trinh, N. T. Son, E. Janzén, J. Suda and T. Kimoto Journal of Applied Physics 115, 143705 (2014)

5. Characterization of the nitrogen split interstitial defect in wurtzite aluminum nitride using density functional theory

A. Szállás, K. Szász, X. T. Trinh, N. T. Son, E. Janzén and A. Gali Journal of Applied Physics 116, 113702 (2014)

6. On the behavior of silicon donor in conductive $\operatorname{Al}_{\mathrm{x}} \mathrm{Ga}_{1-\mathrm{x}} \mathrm{N}$ $(0.63 \leq x \leq 1)$

D. Nilsson, X. T. Trinh, E. Janzén, N. T. Son, and A. KakanakovaGeorgieva

Phys. Status Solidi B

DOI 10.1002/pssb.201451559 


\section{Conference Papers}

1. Electron paramagnetic resonance studies of $\mathrm{Nb}$ in $\mathbf{6 H}-\mathrm{SiC}$

X. T. Trinh, A. Gällström, N. T. Son, S. Leone, O. Kordina, and E. Janzén.

Materials Science Forum 740-742, 385 (2013)

2. Silicon and oxygen in high-Al-content AlGaN: incorporation kinetics and electron paramagnetic resonance study

A. Kakanakova-Georgieva, D. Nilsson, X. T. Trinh, N. T. Son, and E. Janzén.

Solid State Phenomena 205-206, 441 (2014)

3. Identification of the negative carbon vacancy at quasi-cubic site in $4 \mathrm{H}-\mathrm{SiC}$ by EPR and theoretical calculations

X. T. Trinh, K. Szász, T. Hornos, K. Kawahara, J. Suda, T. Kimoto, Á. Gali, E. Janzén and N. T. Son.

Materials Science Forum 778-780, 285 (2014) 


\section{Acknowledgements}

Since I came from Vietnam to Sweden, I had to get acquainted with new culture and completely new research. Without strong supports from my supervisors, my colleagues, my friends and my family, I would not have accomplished this thesis, which was challenging but really enjoyable.

First of all, I want to express my deepest gratitude and highest respect to my supervisors, Professor Nguyen Tien Son and Professor Erik Janzén, for giving me the chance to have this interesting research, for your useful guidance and constant supports. I am truly grateful Professor Erik Janzén for kindness, scientific/financial support and help at any time I needed. I would like to sincerely thank Professor Nguyen Tien Son for setting an excellent research plan, for the great ideal of experiments, for patient explanation, and for helping me to know how to write a nice scientific paper. I have learned the best from both of you and your guidance is truly a treasure for me. It is really my honor and luck to be your $\mathrm{PhD}$ student. I would like to express my sincere gratitude to the family of Professor Nguyen Tien Son, Ngo Thi Tuyet and Nguyen Viet Ha for invaluable advices and for supervision of my life. You gave me a cozy feeling and you are truly my second family. I also would like to express my gratitude and appreciation to Professor Nguyen Duc Chien, former head of School of Engineering Physics at Hanoi University of Science and Technology, for his valuable guidance throughout my studies in Vietnam and for believing in me. With his recommendation, I had a chance to meet Professor Nguyen Tien Son and could start this work.

I want to show my appreciation to all co-authors and collaborators. I want to sincerely thank Associate Professor Anelia Kakanakova-Georgieva and Doctor Daniel Nilsson for growing excellent $\mathrm{AlGaN}$ samples, for discussion about complex properties of $\mathrm{Si}, \mathrm{O}$ and for great contribution to the outcome of this thesis. I would like to thank Associate Professor Ivan Ivanov for effective mass theory calculations and kindly help. I wish to thank Professor Tsunenobu Kimoto, Associate Professor Jun Suda and Doctor Koutarou Kawahara at Kyoto University for preparation of perfect $\mathrm{SiC}$ samples. I really enjoyed the useful discussion with Doctor Koutarou during our EPR measurements and the discovery of mysterious Greek. I want to express my gratitude to Associate Professor Adam Gali, Doctor Krisztián Szász, Doctor Attila 
Szállás, Doctor Tamas Hornos and Viktor Ivády at Wigner Research Centre for Physic, Hungarian Academy of Sciences for detail and precise theoretical calculations as well as writing of nice papers. I wish to give my acknowledgement to Professor Michael Kneissl, Doctor Tim Wernicke and Frank Mehnke at Technische Universität Berlin for your wonderful collaboration in studied of AlGaN. The lab discussion with Frank really helped me to gain knowledge about fabrication process of optoelectronic devices. I wish to thank Associate Professor Masashi Kato and Mr. Hiroki Nakane at Nagoya Institute of Technology for collaboration in studying of $4 \mathrm{H}-\mathrm{SiC}$. I also want to thank Doctor Franziska Beyer at Technische Universität Bergakademie Freiberg for giving me the change to study GaN samples and fruitful discussion about defects in SiC. I would like to thank Professor Bengt Gunnar Svensson, Doctor Lars Sundnes Løvlie at University of Oslo, Professor Junichi Isoya, Associate Professor Takahide Umeda at University of Tsukuba, Doctor Takahiro Makino, Doctor Takeshi Ohshima at Japan Atomic Energy Agency and Associate Professor Olof Kordina, Associate Professor Urban Forsberg, Andreas Gällström, Doctor Stefano Leone in Semiconductor material group for wonderful collaborations. Without these collaborations, I could not finish my challenging researches.

I want to thank Eva Wibom, Kirstin Kahl for administrative issues and Sven Andersson, Roger Carmesten for technical supports. I would like to thank Professor Per Olof Holtz for kindness and giving me financial support of Agora to attend conference. I wish to give my acknowledgement to EPR lab users, Jan Eric Stehr, Yuttapoom Puttisong, Daniel Dagnelund and Håkan Gustafsson, for technical help, sharing equipments and knowledge.

I wish to thank all people in Semiconductor material group and Agora, especially Milan, Pitsiri, Xun, Ian, Chamseddine, Ted, Martin, Pontus, Björn, Chao, Valdas, Sun and others whom I could not mention here, for having a nice working environment. I want to express my special thanks to Thien Duc Tran for close friendship, sarcastic humor and sharing difficulties.

Finally, I would like to express my immense gratitude to my family for giving me unconditional love. I know that my parents understand how important of $\mathrm{PhD}$ student period to my future carrier and their constant encourages are truly the motivation for me to overcome difficul- 
ties. I wish to thank my brothers and sisters to take care of my parents and all my issues in Vietnam. The voices and smiles of my nephew and nieces always make me feel happy and get my mind off stress. I really want to thank my dear Thuy Duong for your love, support, giving me hope and letting me know that I have my own life outside of the university. 


\section{Table of Contents}

Part I. Introduction to the field......................................................... 1

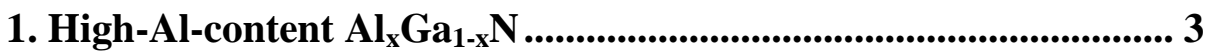

1.1. $N$-type conductivity of high-Al-content $\mathrm{Al}_{\mathrm{x}} \mathrm{Ga}_{1-\mathrm{x}} \mathrm{N}$................... 3

1.2. Negative-U behavior and DX centers ........................................ 4

1.2.2. Concepts of the negative-U and DX centers ................... 4

1.2.2. Statistical analysis of DX center ..................................... 5

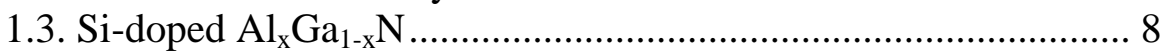

2. Silicon carbide ............................................................................ 10

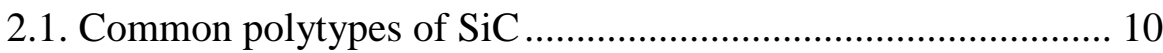

2.2. Carrier lifetime in $\mathrm{SiC}$........................................................... 11

3. Electron paramagnetic resonance .............................................. 14

3.1. Electronic Zeeman interaction and basic principle of EPR ....... 14

3.2. Spin-spin interaction ........................................................ 17

3.3. Hyperfine interaction ........................................................... 18

3.4. Spin-Hamiltonian and angular dependence .............................. 21

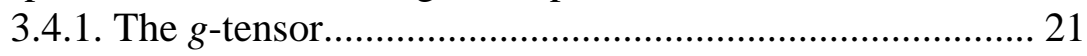

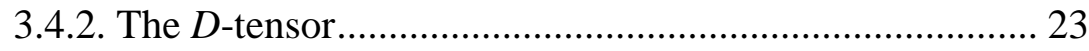

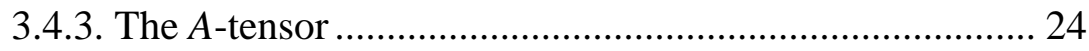

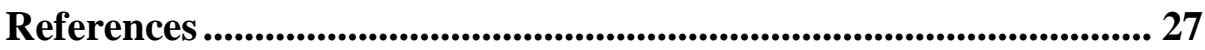

Part II. Papers ….............................................................................. 33

Summary of the papers............................................................................. 35

Paper 1-6 
Part I. Introduction to the field 


\section{High-Al-content $\mathrm{Al}_{\mathrm{x}} \mathrm{Ga}_{1-\mathrm{x}} \mathrm{N}$}

Under the exposure of deep-ultraviolet (UV) radiation with wavelength around $260 \mathrm{~nm}$ or shorter (such as at 214,220 or $228 \mathrm{~nm}$ ) which is often absent in ordinary condition due to the UV absorbance of the ozone shield, DNA or RNA molecules of various micro-organisms are damaged and cannot function or reproduce [1]. Thus, deep-UV radiation can be efficiently used for water/air purification and sterilization [1-3]. The short-wavelength deep-UV radiation can be also used for high resolution lithography and high-density optical data storage. However, conventional deep-UV radiation sources such as gas lasers and mercury lamps are low-energy efficiency and toxic.

The wurtzite AlGaN alloys are the promising materials for the development of light emitters in UV and deep-UV spectral region thanks to their direct and wide band gap. The band gap of $\mathrm{AlGaN}$ increases with increasing of the $\mathrm{Al}$ content varying from $3.4 \mathrm{eV}$ for $\mathrm{GaN}$ to $6.2 \mathrm{eV}$ for AlN [4], which can be used to fabricate the light emitting diodes (LEDs) with a wavelength from $430 \mathrm{~nm}$ for $\mathrm{GaN}$ [4,5] to $210 \mathrm{~nm}$ for AlN [6]. Therefore, the successful fabrication of compact, high-energy efficiency and nontoxic deep-UV LEDs and laser diodes (LDs) based on high-Al-content $\mathrm{Al}_{\mathrm{x}} \mathrm{Ga}_{1-\mathrm{x}} \mathrm{N}(\mathrm{x} \geq 70 \%)$ [6-8] will have an enormous social impact. High $n$-type and $p$-type conductivity $\mathrm{Al}_{\mathrm{x}} \mathrm{Ga}_{1-\mathrm{x}} \mathrm{N}$ are required for electrically pumped LEDs and LDs. Although a considerable progress has been made in $n$-type and $p$-type doping of high-Al-content $\mathrm{Al}_{\mathrm{x}} \mathrm{Ga}_{1-}$ ${ }_{x} \mathrm{~N}$, there are still fundamental issues related to dopants, doping and carrier compensation to be solved.

\section{1. $N$-type conductivity of high-Al-content $\mathrm{Al}_{\mathrm{x}} \mathrm{Ga}_{1-\mathrm{x}} \mathrm{N}$}

Silicon ( $\mathrm{Si}$ ) is the most commonly used dopant for $n$-type doping of $\mathrm{AlGaN}$ alloys while oxygen $(\mathrm{O})$ is the most common residual impurity in the material. Achieving high $n$-type conductivity in high-Al-content $\mathrm{Al}_{\mathrm{x}} \mathrm{Ga}_{1-\mathrm{x}} \mathrm{N}: \mathrm{Si}(\mathrm{x}>0.7)$ is proven difficult [9-11]. Generally, it is expected that higher doping concentration leads to higher conductivity. However, the conductivity was found to increase to maximal value at a certain $\mathrm{Si}$ doping concentration and then to decrease with further increasing of the $\mathrm{Si}$ concentration in high-Al-content AlGaN [11-13]. It was suggested that $\mathrm{Si}$ did not only replace group-III atoms ( $\mathrm{Ga}$ or $\mathrm{Al})$ to form isolated donors, but might also introduce other Si-related deep-energy-level de- 
fects such as $\mathrm{Si}$ antisite, $\mathrm{Si}_{\mathrm{N}}$, at high doping level and caused selfcompensation effect [12]. In addition, other studies reported problems caused by heavily $\mathrm{Si}$ doping such as the formation of cracks [14] or pits [15] on the surface.

High resistivity observed in Si-doped high-Al-content AlGaN was often speculated to be due to either the formation of the so-called DX centers of $\mathrm{Si}$ or the presence of deep defects, including cation $(\mathrm{Ga}$ and $\mathrm{Al}$ ) vacancies and/or other impurities such as $\mathrm{O}, \mathrm{C}$ and $\mathrm{H}$, which act as carrier compensation centers. For $\mathrm{O}$, it has been suggested that the substitutional $\mathrm{O}_{\mathrm{N}}$ is a DX center [16-19] and can also form complexes with cation vacancies acting as deep acceptors [20,21]. The substitutional $\mathrm{C}_{\mathrm{Ga}}$ was suggested to be a shallow donor in $\mathrm{GaN}[22,23]$ but the substitutional $\mathrm{C}_{\mathrm{Al}}, \mathrm{C}_{\mathrm{N}}$, interstitial $\mathrm{C}_{\mathrm{i}}[23]$ and a cluster of three carbon atoms [24] were suggested to introduce deep acceptor levels in AlN. Isolated interstitial $\mathrm{H}$ was also suggested to be deep electron trap in $n$ type material of both GaN and AlN [25].

\subsection{Negative-U behavior and DX centers}

\subsubsection{Concepts of the negative- $U$ and $D X$ centers}

The concept of negative-U defects in semiconductors was initially introduced by Anderson [26]. The Coulomb repulsion between two electrons is positive and causes the energy level of two-electron state higher than that of one-electron state. However, in certain cases, the energy of two-electron state is reduced by electron pairing and a lattice relaxation of the defect [26]. If the energy reduction of these attractive interactions is smaller than energy of the Coulomb repulsion, the effective change of energy after capturing the second electron, $\mathrm{U}$, is positive (positive- $\mathrm{U}$ behavior). If the energy earned from the attractive interactions overcomes the energy of the Coulomb repulsion, the energy $U$ is negative (negative-U behavior). In darkness at low temperatures, the paired electron state (electron spin $S=0$ and, hence, is EPR inactive) of a negative$\mathrm{U}$ defect has lower energy and is the stable state of the defect, while the unpaired electron state ( $S=1 / 2$ and EPR active) of the defect is metastable. When the energy separation between the two levels is large, the thermal induced population on the unpaired electron state at low temperatures in darkness may be below the detection limit of EPR. In such case, the observation of the EPR signal of the negative- $U$ center requires 
thermal energy at elevated temperatures or illumination to increase the population on the unpaired electron state. When the paired electron state lies only a few meV below the unpaired electron state, the population of the unpaired electron state at low temperatures in darkness can be detectable by EPR [27,28].

The term DX was first used by Lang et al. [29,30] for a dominant deep level defect which was suggested as a complex between the Te donor and unidentified component in $\mathrm{Al}_{\mathrm{x}} \mathrm{Ga}_{1-\mathrm{x}} \mathrm{As}$. Later study showed that DX centers could be formed in GaAs under hydrostatic pressure which increased the band gap in similar way as increasing the Al content in $\mathrm{Al}_{\mathrm{x}} \mathrm{Ga}_{1-\mathrm{x}} \mathrm{As}$ and suggested that $\mathrm{DX}$ centers can be isolated donors [31]. The term DX becomes common for a donor that has negative$\mathrm{U}$ properties with its negatively charged state $\mathrm{DX}^{-}$lying deeper than the neutral state. Therefore, in equilibrium the donor in its neutral charge state $d^{0}$ tends to capture another electron to lower its energy. This process forms a deeper negatively charged state $\mathrm{DX}^{-}$and an ionized donor state $\mathrm{d}^{+}$according to the reaction $2 \mathrm{~d}^{0} \rightarrow \mathrm{DX}^{-}+\mathrm{d}^{+}$and, thus, the donor acts as an electron trap, leading to self-compensation of carriers [32].

It has been known that several configurations of a DX center can be coexistent. The model of large lattice relaxation of DX was suggested by several studies [29,30,32]. There were also suggestion of DX models with small lattice relaxation in which the position of the DX center is close to the substitutional site [33-36]. Chadi [37] suggested the existence of different negative [38] and neutral charge states [39] of DX centers corresponding to different distortions around the impurities. Other studies suggested different DX configurations of $\mathrm{Si}$ in $\mathrm{Al}_{\mathrm{x}} \mathrm{Ga}_{1-\mathrm{x}} \mathrm{As}$ to be related to different numbers of $\mathrm{Al}$ atoms surrounding the isolated Si donor [40-42]. In addition, the negative charge state of a DX center and the positively charged donor were theoretically suggested to form a complex (denoted DDX) at high doping concentration via Coulomb interaction [43]. In that case, the DDX center is more stable than the single DX center and its formation increases further self-compensation effect. The above issues make the study of DX centers more complicate but also of great fundamental defect physics and technological interests.

\subsubsection{Statistical analysis of $D X$ center}

The population on the $\mathrm{d}^{+}, \mathrm{d}^{0}$ and $\mathrm{DX}^{-}$states [denoted as $\mathrm{N}_{\mathrm{d}}^{+}, \mathrm{n}(\mathrm{T})$ and 
$\mathrm{N}_{\mathrm{DX}}$, respectively] can be described by using the statistical model of amphoteric impurities with three electronic charge states: $\mathrm{d}^{+}$at the conduction band minimum (with degeneration factor of 1 and spin polarization $M_{\mathrm{S}}=0$ ), $\mathrm{d}^{0}$ at $\mathrm{E}_{\mathrm{d}}$ (with a degeneration factor of 2 corresponding to two spin states with $M_{\mathrm{S}}= \pm 1 / 2$ ), and $\mathrm{DX}^{-}$at $\mathrm{E}_{\mathrm{DX}}$ (with a degeneration factor of $1, M_{\mathrm{S}}=0$ ) [44]

$$
\begin{aligned}
\frac{\mathrm{N}_{\mathrm{d}}^{+}}{\mathrm{n}(\mathrm{T})} & =\frac{1}{2} \exp \left(\frac{\mathrm{E}_{\mathrm{d}}-\mathrm{E}_{\mathrm{F}}}{\mathrm{k}_{\mathrm{B}} \mathrm{T}}\right) \\
\frac{\mathrm{n}(\mathrm{T})}{\mathrm{N}_{\mathrm{DX}}} & =2 \exp \left(\frac{\mathrm{E}_{\mathrm{DX}}-\mathrm{E}_{\mathrm{F}}}{\mathrm{k}_{\mathrm{B}} \mathrm{T}}\right) .
\end{aligned}
$$

From above equations, one can obtain

$$
\begin{aligned}
& \mathrm{N}_{\mathrm{DX}}=\frac{0.5 \mathrm{~N}_{\mathrm{d}} \exp \left(\frac{\mathrm{E}_{\mathrm{F}}-\mathrm{E}_{\mathrm{DX}}}{\mathrm{k}_{\mathrm{B}} \mathrm{T}}\right)}{1+0.5 \exp \left(\frac{\mathrm{E}_{\mathrm{d}}-\mathrm{E}_{\mathrm{F}}}{\mathrm{k}_{\mathrm{B}} \mathrm{T}}\right)+0.5 \exp \left(\frac{\mathrm{E}_{\mathrm{F}}-\mathrm{E}_{\mathrm{DX}}}{\mathrm{k}_{\mathrm{B}} \mathrm{T}}\right)} \\
& \mathrm{n}(\mathrm{T})=\frac{\mathrm{N}_{\mathrm{d}}}{1+0.5 \exp \left(\frac{\mathrm{E}_{\mathrm{d}}-\mathrm{E}_{\mathrm{F}}}{\mathrm{k}_{\mathrm{B}} \mathrm{T}}\right)+0.5 \exp \left(\frac{\mathrm{E}_{\mathrm{F}}-\mathrm{E}_{\mathrm{DX}}}{\mathrm{k}_{\mathrm{B}} \mathrm{T}}\right)} .
\end{aligned}
$$

Here $\mathrm{N}_{\mathrm{d}}=\mathrm{N}_{\mathrm{d}}^{+}+\mathrm{n}(\mathrm{T})+\mathrm{N}_{\mathrm{DX}}$ is the total concentration of the donor (with neglecting all the excited states of the donor), $\mathrm{k}_{\mathrm{B}}$ is the Boltzmann constant. The Eq. (1) can also be obtained by using the statistics of multi-charge center [45-47]. In this case, there are three states for a DX center: $\mathrm{d}^{+}$state without occupied electron and neutral charge state (degeneration factor is 2 corresponding to two states with $M_{S}= \pm 1 / 2$ ) with one occupied electron and one DX state with two occupied electrons. The total energy of electrons on the $\mathrm{d}^{+}, \mathrm{d}^{0}$ and $\mathrm{DX}^{-}$states are $0, \mathrm{E}_{\mathrm{d}}$ and $2 E_{d}-\left(E_{d}-E_{D X}\right)$, respectively (the negative correlation energy $U=E_{d}-E_{D X}$ is the energy that the negative-U center can reduce by capture the second electron). The detail of the interpretation can be found elsewhere [4547].

It has also been shown that in a negative-U center, the Fermi level varies only very slowly with electronic density and temperature and is effectively pinned at the middle of the two populated levels (i.e. $E_{d}$ and $\mathrm{E}_{\mathrm{DX}}$ levels for a DX center) $[45,47]$. These studies showed that the Fer- 


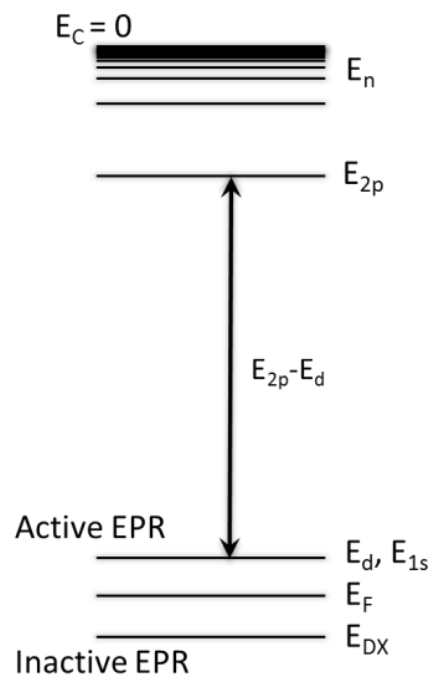

Figure 1. The scheme of energy levels of a DX center, including the neutral charge $\mathrm{E}_{\mathrm{d}}$ (active $\mathrm{EPR}$ ), negatively charged $\mathrm{E}_{\mathrm{DX}}$ (inactive EPR), the first excited state $E_{2 p}$ and higher excited states $E_{n}$. $E_{C}$ is the conduction band minimum. Under the thermal equilibrium and at low temperatures, the Fermi level is approximated at the middle between $\mathrm{E}_{\mathrm{d}}$ and $\mathrm{E}_{\mathrm{DX}}$ levels when the concentrations of other defects are negligible.

mi level is almost constant when the average number of electrons per DX center $\left[n_{a v}=\left(2 N_{D X}+n(T)\right) / N_{d}\right]$ varies from close to 0 to 2 . At low temperatures, the concentration of free carrier in the conduction band is small and thus, most of electrons stay in either $E_{d}$ or $E_{D x}$ levels (i.e $\left.\mathrm{n}_{\mathrm{av}} \sim 1\right)$ when the concentrations of other defects are negligible. Within the error of determination of energy level, the Fermi level in our studied AlGaN layers can be approximated at the middle of $E_{d}$ and $E_{D x}$ levels (i.e. $\mathrm{E}_{\mathrm{F}}-\mathrm{E}_{\mathrm{DX}} \sim \mathrm{E}_{\mathrm{d}}-\mathrm{E}_{\mathrm{F}}$ ) and Eq. (1) is rewritten as

$$
n(T)=\frac{N_{d}}{1+\exp \left(\frac{E_{d}-E_{F}}{k_{B} T}\right)} .
$$

With including the excited states of donors (Fig. 1) [44,46,47], the temperature dependence of the population on the $\mathrm{d}^{0}$ state of a DX center can be described as [28] 


$$
\mathrm{n}(\mathrm{T})=\frac{\mathrm{N}_{\mathrm{d}}}{1+\exp \left(\frac{\mathrm{E}_{\mathrm{d}}-\mathrm{E}_{\mathrm{F}}}{\mathrm{k}_{\mathrm{B}} \mathrm{T}}\right)+0.5 \sum_{\mathrm{i}} \mathrm{G}_{\mathrm{i}} \exp \left(\frac{\mathrm{E}_{\mathrm{d}}-\mathrm{E}_{\mathrm{i}}}{\mathrm{k}_{\mathrm{B}} \mathrm{T}}\right)} .
$$

Here, $G_{i}$ is the degenerate factor of corresponding excited states. Considering only the first excited state ( $2 \mathrm{p}$ or $2 \mathrm{~s}$ ), Eq. (3) can be rewritten as

$$
\mathrm{n}(\mathrm{T})=\frac{\mathrm{N}_{\mathrm{d}}}{1+\exp \left(\frac{\mathrm{E}_{\mathrm{d}}-\mathrm{E}_{\mathrm{F}}}{\mathrm{k}_{\mathrm{B}} \mathrm{T}}\right)+\operatorname{Cexp}\left(\frac{\mathrm{E}_{\mathrm{d}}-\mathrm{E}_{2 \mathrm{p}}}{\mathrm{k}_{\mathrm{B}} \mathrm{T}}\right)} .
$$

Here, $E_{2 p}-E_{d}$ is the energy distance from $d^{0}\left(E_{d}\right.$ or $\left.E_{1 s}\right)$ to the first excited state (2p or $2 s)$ and $\mathrm{C}$ is the total degenerate factor of excited states within $\mathrm{k}_{\mathrm{B}} \mathrm{T}$ from the first excited state. The number of spins or the neutral donor concentration obtained from EPR experiments with considering the temperature effect and measurement conditions is directly proportional with $n(T)$ determined from Eq. (4). Thus, the energy distance $E_{d}-E_{F}$ and $E_{2 p}-E_{d}$ can be obtained from the fits of experiment data using Eq. (4). The $E_{d}$ can be obtained as $\left|E_{d}\right|=4\left|E_{2 p}-E_{d}\right| / 3$ when the energy levels of excited states of the donor are assumed to follow the effective mass theory [i.e. the $E_{d} / i^{2}$ rule $(i=1,2, . ., n)$ or $E_{2 p} \sim E_{d} / 4$ and $\left|E_{2 p}-E_{d}\right|$ $\left.=\left|\left(E_{d} / 4\right)-E_{d}\right|=3\left|E_{d}\right| / 4\right]$. Since the Fermi level is approximated at the middle of $\mathrm{E}_{\mathrm{d}}$ and $\mathrm{E}_{\mathrm{DX}}$, the $\mathrm{E}_{\mathrm{DX}}$ level is estimated to be $\left|\mathrm{E}_{\mathrm{DX}}\right| \sim\left|\mathrm{E}_{\mathrm{d}}\right|+2 \mid \mathrm{E}_{\mathrm{d}^{-}}$ $\mathrm{E}_{\mathrm{F}}$.

\subsection{Si-doped $\mathrm{Al}_{\mathrm{x}} \mathrm{Ga}_{1-\mathrm{x}} \mathrm{N}$}

Silicon doping was performed during metal-organic chemical vapor deposition (MOCVD) growth of $\mathrm{Al}_{\mathrm{x}} \mathrm{Ga}_{1-\mathrm{x}} \mathrm{N}$ epilayers. The precursor gases were TMAl, TMGa and $\mathrm{NH}_{3}$ while the dopant gas was silane $\left(\mathrm{SiH}_{4}\right)$. The small lattice mismatch between $4 \mathrm{H}-\mathrm{SiC}$ and high-Alcontent $\mathrm{Al}_{\mathrm{x}} \mathrm{Ga}_{1-\mathrm{x}} \mathrm{N}$ allows obtaining layers with less strain and better crystal quality. In our studied samples, a buffer AlN layer of 500-600 $\mathrm{nm}$ was initially grown on $4 \mathrm{H}-\mathrm{SiC}$ substrate and a grade $\mathrm{Al}_{\mathrm{x}} \mathrm{Ga}_{1-\mathrm{x}} \mathrm{N}$ layer with the total thickness of $\sim 400 \mathrm{~nm}$ was grown subsequently. Finally, the $\mathrm{Si}$ doped $\mathrm{Al}_{\mathrm{x}} \mathrm{Ga}_{1-\mathrm{x}} \mathrm{N}$ epilayers was deposited on the top of the template as can be seen in the Secondary Ion Mass Spectroscopy (SIMS) profile shown in Fig. 2. In our studies of $\mathrm{Si}$ in $\mathrm{AlGaN}[15,27,28]$, the 
concentrations of residual $\mathrm{C}$ and $\mathrm{O}$ were often kept at $\sim 1-2 \times 10^{17} \mathrm{~cm}^{-3}$, which is about one order of magnitude below the Si concentration ([Si] $2 \times 10^{18} \mathrm{~cm}^{-3}$ ) (Fig. 2), in order to reduce their complex impact on the $n$ type doping. More details on MOCVD growth and Si doping of highAl-content AlGaN can be found elsewhere [15,48,49].

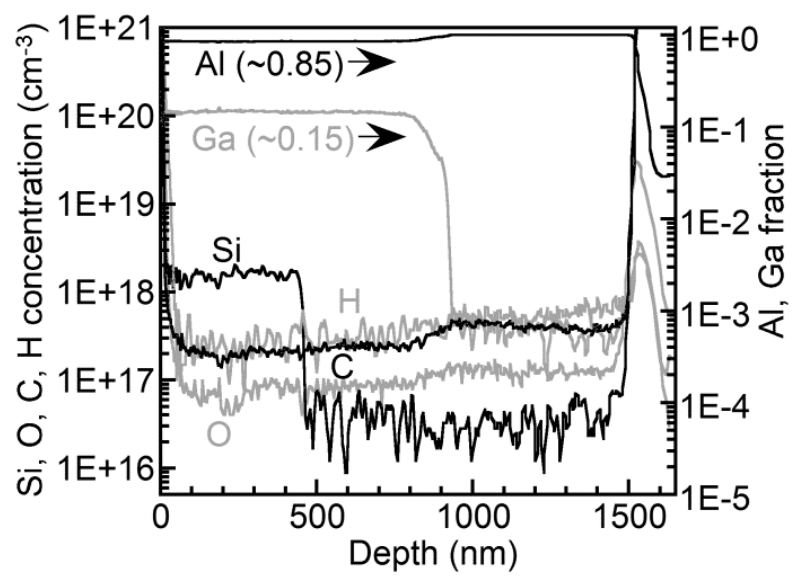

Figure 2. SIMS profile showing typical structures of Si-doped AlGaN layers grown on semi-insulating $4 \mathrm{H}-\mathrm{SiC}$ substrate, the $\mathrm{Al}$ content, atomic concentration of $\mathrm{Si}$ and other common residual impurities $(\mathrm{O}, \mathrm{C}$, and $\mathrm{H})$. 


\section{Silicon carbide}

The formation of chemical bond between silicon and carbon was first suggested by Swedish chemist Jöns Jakob Berzelius in 1824. He was considered as the first person who discovered silicon carbide (SiC) [50]. The first synthesized SiC powder carried out by Edward Goodrich Acheson was patterned in 1893. At that time, SiC was used as an abrasive material and was called "carbonrundum" by its author. The nature mineral of $\mathrm{SiC}$ was found much later in 1905 due to its extremely rare naturally occurring and was named as moissanite in honor of Henri Mossan, who discovered it [50]. Since 1955, several growth methods [51-53] have been developed and the crystal quality of SiC has constantly been improved, allowing electronic device applications.

\subsection{Common polytypes of $\mathrm{SiC}$}

Silicon carbide can exist in more than 200 types of polytypes in which the most common and technologically important ones are $3 \mathrm{C}-, 4 \mathrm{H}-$ and $6 \mathrm{H}-\mathrm{SiC}$ [54]. The polytypes can be viewed as the different stacking sequence of bi-layers of $\mathrm{Si}$ and $\mathrm{C}$ atoms along the $c$-axis. The notation of each polytype consists of a minimal number of bi-layers along the $c$ axis required for the periodicity of crystal structure and a letter describing the crystal system (C-cubic, H-hexagonal and R-rhombohedral). For
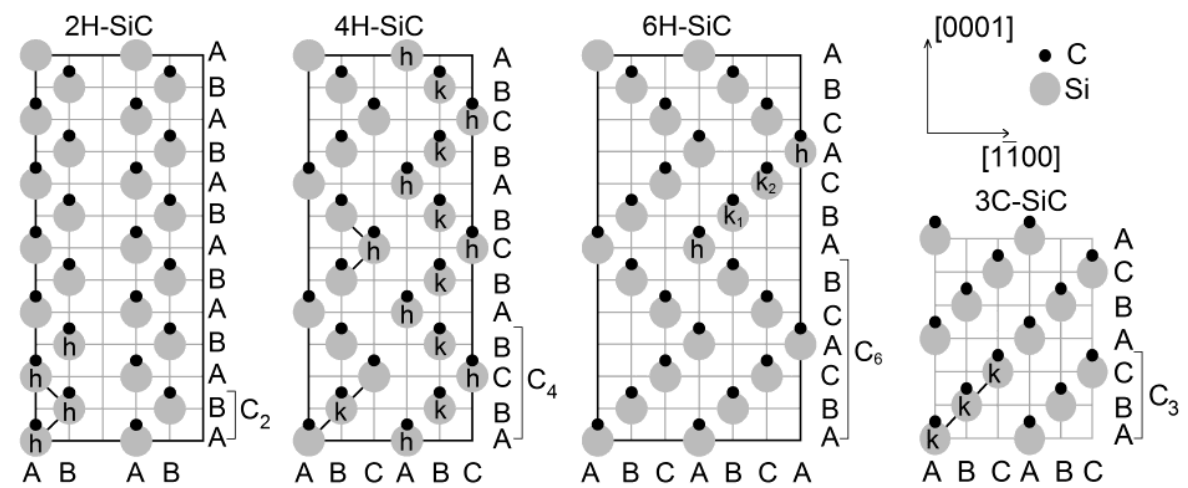

Figure 3. The (11 $\overline{2} 0)$ plane of $2 \mathrm{H}-, 4 \mathrm{H}-, 6 \mathrm{H}-\mathrm{SiC}$, and the (110) plane (the vertical axis is the [111] direction) of the 3C-SiC polytye. The $\mathrm{Si}$ atoms at $h, k, k_{1}, k_{2}$-sites are indicated. The solid lines are used to guide the eyes for the arrangement of the second nearest neighbors of a $\mathrm{Si}$ atom at the $h$ and $k$-sites. The figure is adapted from Ref. [54]. 
example, the 3C-SiC polytype has the zinc blende structure with 3 bilayers periodicity of $\mathrm{Si}$ and $\mathrm{C}$ atoms along the [111] direction (equivalent to the $c$-axis in other $\mathrm{SiC}$ polytypes) (Fig. 3).

The different crystal structure of $\mathrm{SiC}$ polytypes results in different physical properties such as the band gap. The physical reason of the variation of the band gaps of $\mathrm{SiC}$ polytypes from $\sim 2.40 \mathrm{eV}$ in $3 \mathrm{C}$ to $\sim 3.33 \mathrm{eV}$ in $2 \mathrm{H}$ has been of great interest. Choyke et al. found that the band gap of $\mathrm{SiC}$ polytypes increases almost linearly with the percentages of hexagonal sites present in the polytypes [55]. For example, 3C with $0 \%$ of hexagonal site has the smallest band gap, while the $2 \mathrm{H}$ lattice is a pure hexagonal and the polytype has the widest band gap. However, other physical reason has also been suggested to explain the variation of the band gap of different $\mathrm{SiC}$ polytypes. Recently, Matsushita et $a l$. found that the floating electron cloud distributes in the interstitial channel causing the narrowing of band gap in SiC [56]. The authors suggested that the length of interstitial channels (the number of bilayers along the longest interstitial channels) can be used to explain the variation of band gap for $\mathrm{SiC}$ polytypes better than the hexagonality [57].

There are different inequivalent sites in the crystal structure of $\mathrm{SiC}$ polytypes. In $3 \mathrm{C}-\mathrm{SiC}$, the crystal has the zinc blende structure with all atoms having similar environment of cubic crystal, while in the hexagonal polytypes, e.g. $4 \mathrm{H}-\mathrm{SiC}$, there are different inequivalent lattice sites: $h$-site or hexagonal site, where the second nearest neigboring atoms are arranged following wurtzite structure, and $k$-site or quasi-cubic site with the arrangement of the second nearest neighboring atoms similar to that of zinc blende. In $6 \mathrm{H}-\mathrm{SiC}$, there are three inequivalent lattice sites: $h, k_{1}$ and $k_{2}$. It is expected that a defect occupying different inequivalent sites has different properties. For example, nitrogen $(\mathrm{N})$ substituting for $\mathrm{C}$ atoms at three inequivalent sites $\left(h, k_{l}\right.$ and $k_{2}$-sites) in $6 \mathrm{H}$ $\mathrm{SiC}$ are three $\mathrm{N}$ shallow donor centers having different electrical, optical and magnetic properties [58]. For another example, EPR spectra of the carbon vacancies at different inequivalent sites in $4 \mathrm{H}-\mathrm{SiC}$ ( $h$ and $k$-sites) are distinguishable [59-62].

\subsection{Carrier lifetime in $\mathrm{SiC}$}

Having superior properties such as high breakdown field, high-thermal conductivity, and large saturated electron drift velocity, $\mathrm{SiC}$ has been considered as a promising material for high-voltage and high-power 
devices which can operate at high temperatures and in harsh environment $[63,64]$.

In high-voltage, high-frequency devices, the carrier lifetime is an important factor. For high-voltage bipolar devices, such as PiN diodes, bipolar junction transistor and thyristors, operating under high-injection conditions, using conductivity modulation can help to reduce the onstate resistance of the devices and, hence, the power losses. In such devices, the increase of excess carrier concentration during the avalanche and injection processes results in the increase of the conductivity of particular region and this effect is defined as the conductivity modulation [65]. The presence of a high excess carrier concentration which contributes to conductivity is governed by carrier lifetime. Long carrier lifetime under high injection condition is required to obtain effective conductivity modulation that helps to reduce the on-state resistance [6668]. For high-voltage device, a higher operating voltage requires a thicker layer to block the voltage and longer carrier lifetime is needed. In $4 \mathrm{H}-\mathrm{SiC}$, a carrier lifetime required for the effective conductivity modulation is about $5 \mu$ s for the device with blocking voltage of $10 \mathrm{kV}$ and longer than $20 \mu$ s for $20 \mathrm{kV}$ [69].

In semiconductor materials, the carrier lifetime is influenced by four recombination processes of electrons and holes which include radiative recombination, Auger recombination, recombination at surfaces or at interfaces, and the Shockley-Read-Hall (SRH) recombination [66]. The radiative recombination is the band-to-band recombination, resulting in a photon emission. In indirect-band-gap semiconductors, such as $\mathrm{SiC}$, the radiative recombination is insignificant since it requires the participation of extra phonons. The Auger recombination also requires the participation of three particles and only becomes significant under high injection levels. The surface recombination is due to defects present at the surface or interface and this process can play an important role to the carrier lifetime. Finally, the SRH process $[70,71]$ is the process in which a deep level defect first captures an electron from the conduction band and subsequently captures a hole from the valence band (or vice versa). The SRH process becomes stronger with deeper energy level of the defect as well as its higher concentration and larger electron and hole capture cross sections [70,71].

The carrier lifetime in as-grown bulk $4 \mathrm{H}-\mathrm{SiC}$ is often $\sim 0.5-2$ $\mu \mathrm{s}$ [72-75]. It has been known that the carrier lifetime killer defect in 
as-grown bulk $4 \mathrm{H}-\mathrm{SiC}$ is the $\mathrm{Z}_{1} / \mathrm{Z}_{2}$ deep level [72,74,76-78]. The $\mathrm{Z}_{1} / \mathrm{Z}_{2}$ $(\sim 0.65 \mathrm{eV}$ below the conduction band minimum [79,80]) is one of the most common deep levels detected by deep level transient spectroscopy (DLTS) in as-grown material [80]. To enhance the carrier lifetime in $4 \mathrm{H}-\mathrm{SiC}$, the $\mathrm{Z}_{1} / \mathrm{Z}_{2}$ deep level needs to be eliminated. However, this center is very thermally stable [79]. It has been found that the concentration of the $\mathrm{Z}_{1} / \mathrm{Z}_{2}$ in as-grown materials can be significantly reduced by $\mathrm{C}$ implantation and subsequent annealing [81] or by thermal oxidation [69]. Recently, a long carrier lifetime of $\sim 20-30 \mu$ s has been achieved by using either $\mathrm{C}$ implantation and subsequent annealing [82] or using thermal oxidation and surface passivation with a nitrided oxide [83]. 


\section{Electron paramagnetic resonance}

The first successful experiments of EPR (also known as Electron Spin Resonance or ESR) were performed by Zavoisky [84] in 1944. The detail about early history of magnetic resonance techniques was given by Ramsey [85]. Since its discovery, EPR has been developed and become a powerful method for researchers in various fields [86] (pages 7 and 8).

\subsection{Electronic Zeeman interaction and basic principle of EPR}

Under external magnetic field, the energy levels of an unpaired-electron center are separated to multi levels due to the interaction between magnetic field and the total angular momentum of the center and this effect is called Zeeman effect [87]. The total angular momentum of an unpaired-electron center ( $\mathbf{J})$ has two components: spin angular momentum (S) and orbital angular momentum $(\mathbf{L})$. The magnetic moment caused by the total angular momentum $\mathbf{M}$ is given by $\mathbf{M}=-g \mu_{\mathrm{B}} \mathbf{J}$ (the negative sign is due to negative electronic charge of electron). Thus, the Hamiltonian of the interaction between an external magnetic field $\mathbf{B}$ and the total angular momentum is described as

$$
H=-\mathbf{M B}=\mu_{\mathbf{B}} \mathbf{B} . \mathbf{g} . \mathbf{J} \text {. }
$$

Here, $\mu_{\mathrm{B}}=9.27400968 \times 10^{-24} \mathrm{~J} \mathrm{~T}^{-1}$ is the Bohr magneton and $g$ is the splitting factor of the energy levels. In classical theory, the $g$ factor was given by following Landé formula in which the electron spin $g_{\mathrm{e}}$ factor and the electron orbital $g_{\mathrm{L}}$ factor are equal to 2 and 1 , respectively (Ref. [88], page 141).

$$
g=\frac{3}{2}+\frac{S(S+1)-L(L+1)}{2 J(J+1)}
$$

In many cases, the orbital angular momentum of the unpairedelectron center in crystal solid is quenched $(\mathbf{L}=0)$ and thus, the total angular momentum $\mathbf{J}$ in Eq. (5) is often replaced spin angular momentum S. In this case, the $g$ factor in Eq. (6) is equal 2. It was found that the electron spin $g_{\mathrm{e}}$ factor for a free electron is indeed $\sim 2.002319$ [89]. Using quantum theory, the deviation of the value from 2 was calculated by J. Schwinger [90]. 

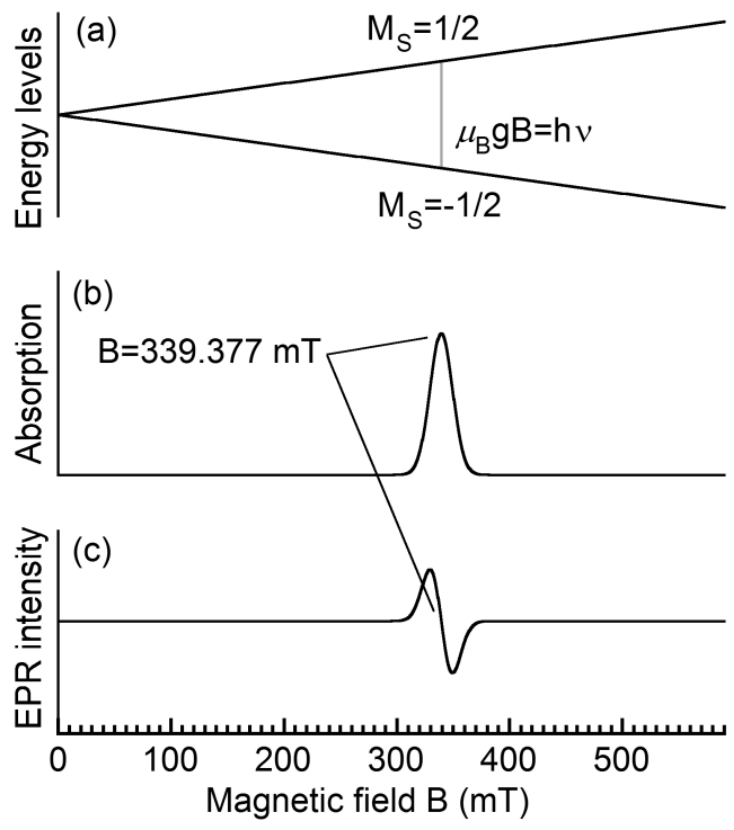

Figure 4. (a) The separated energy levels of an unpaired electron $(S=1 / 2, L=0)$ under external magnetic field, (b) the absorption of microwave and (c) the EPR signal obtained from the derivation of the absorption. For simulation, $g=2$ and the microwave frequency is 9.5 $\mathrm{GHz}$.

The principle of EPR is based on the Zeeman effect and the interaction among electron spins and nuclear spins of the spin center. The energy splits of energy levels caused by those interactions are often equal the energy of photon of a microwave. Therefore, transitions between the splitting energy levels can be induced by absorption or emission of photons of microwave. The resonance absorption of the microwave occurs when the energy separation between two levels is equal to the photon energy of microwave. For a simplest case when the electron spin $S=1 / 2$ and without the presence of the orbital angular momentum $(\mathbf{L}=0)$, the energy level is split into two sublevels under external magnetic field and there is only one resonance absorption corresponding to the transition between the two levels (for the case of the electronic 
Zeeman interaction being isotropic). The observed EPR signal is often obtained from the derivation of the absorption (Fig. 4).

In practice, the applied magnetic field is swept and controlled by the magnetic-field controller. The typical components of an EPR spectrometer are shown in Fig. 5. The generation of a constant frequency microwave and the detection of the absorption signal are processed by the microwave bridge. The sample is kept inside a cavity which acts as a resonator of the microwave, creating standing waves. For angular dependence measurements, either the sample or the magnet is rotated. In our study using the Bruker X-band $(\sim 9.5 \mathrm{GHz})$ E500 spectrometer, the samples were rotated to obtain the angular dependence of the magnetic field positions of EPR lines. With the microwave frequency of $9.5 \mathrm{GHz}$, the magnetic field position of the EPR line is $339.377 \mathrm{mT}$ when $g=2$. The cavity can be equipped with a cryostat allowing the regulation of the sample temperature in the range of 4-295 K. The quality factor Q of the cavity is defined as the ratio between the energy stored and the energy lost during a period of microwave. Higher Q factor indicates the higher sensitivity of the EPR spectrometer. The signal-to-noise ratio of the absorption of the microwave is enhanced using a lock-in amplifier.

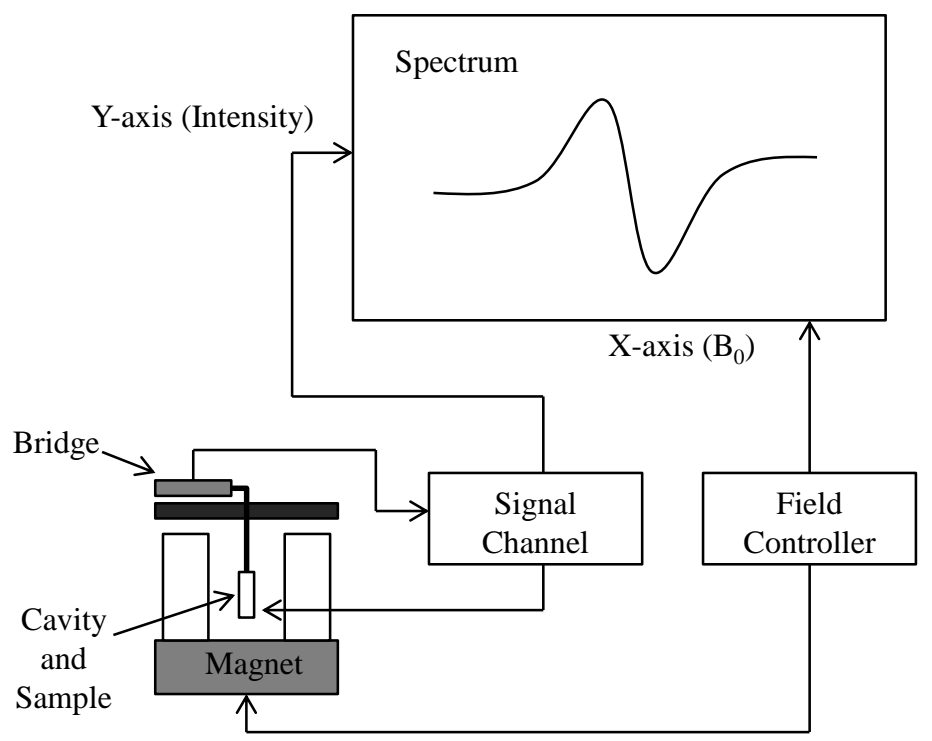

Figure 5. The typical block diagram of an EPR system (adapted from Ref. [91]). 
Finally, the dependence of the recorded EPR intensity on the applied magnetic field, i.e. the EPR spectrum, is recorded [91].

\subsection{Spin-spin interaction}

For a spin system having electron spin $S \geq 1$, there will be spin-spin interaction among the unpaired electrons. This interaction splits up the energy level in absence of the external magnetic field. The splitting is therefore called zero-field splitting or fine-structure splitting [92]. The spin-spin interaction has two components, electron-exchange interaction and electron-electron dipole interaction. The electron-exchange interaction is related to the electric Coulomb interaction of unpaired electrons
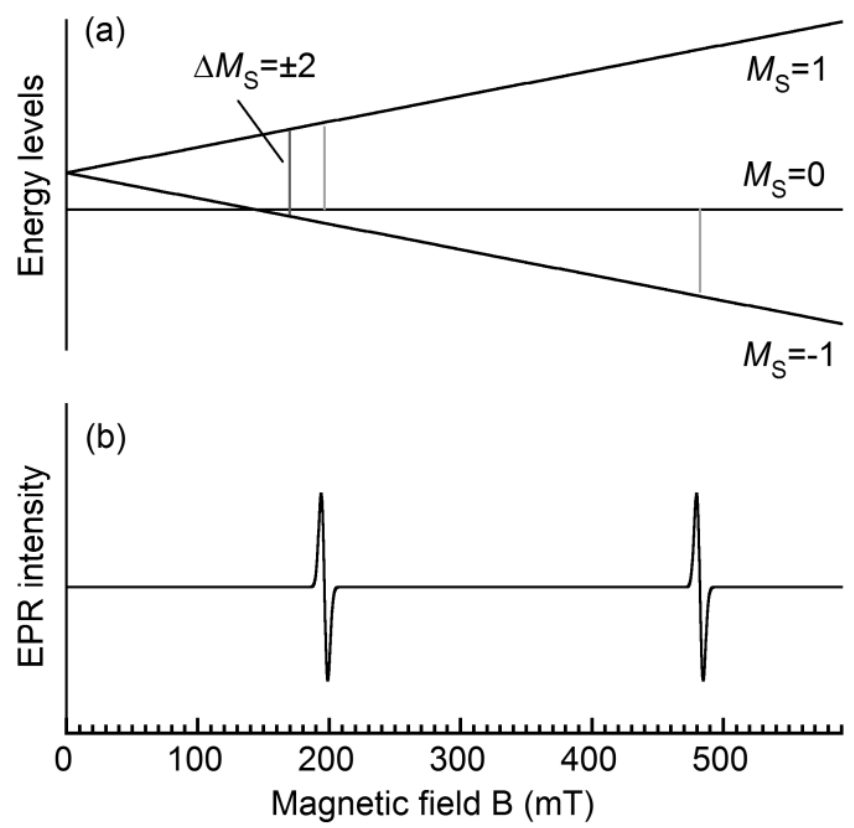

Figure 6. (a) The scheme of energy levels and (b) corresponding simulated EPR spectrum of an impurity with an electron spin $S=1$ and $\mathbf{B} \| \mathbf{Z}$ ( $g=2, D=4000 \mathrm{MHz}, E=0$ and the microwave frequency is $9.5 \mathrm{GHz}$ ). The vertical lines in figure (a) indicate the allowed transitions which give rise to the EPR lines observed in figure (b). The forbidden transition with $\Delta M_{\mathrm{S}}= \pm 2$ is also indicated. 
while the electron-electron dipole interaction is related to their magnetic interaction [86] (pages 159-164).

The Hamiltonian related to the spin-spin interaction is given as S.D.S. Thus, the number of the energy levels split by the spin-spin interaction is equal to the number of the values of $\left|M_{\mathrm{S}}\right|$. For a spin center which has $S=1$, the level will split into two levels at zero field $(\mathrm{B}=0)$ and will be separated to three levels under an external magnetic field. The dependence of these energy levels on B [86] (pages 165-172) is shown in Fig. 6(a). The allowed transition between two levels has to follow the selection rules in which $\Delta M_{\mathrm{S}}= \pm 1$. Thus, there are two observed EPR lines corresponding two allowed transitions when $S=1$ [Fig. 6(b)]. When the zero-field splitting is relatively large compare to electronic Zeeman interaction, the forbidden transitions with $\Delta M_{\mathrm{S}}= \pm 2$ or larger could be observed in EPR spectrum [93].

\subsection{Hyperfine interaction}

When the wave function of unpaired electron overlaps with an impurity which has a nuclear spin $I \neq 0$, there will be an interaction between the electron spin and the nuclear spin. This interaction is called hyperfine interaction since the split of the energy levels caused by this interaction is often smaller than that of the electronic Zeeman interaction and spinspin interaction. If both the unpaired electron and the nuclear spin are belonged to the same atom, the hyperfine interaction is called selfhyperfine interaction. In the case the hyperfine interactions are caused by the unpaired electron and the nuclear spins of its neighbor atoms, these interactions are called ligand-hyperfine interaction.

The Hamiltonian related to the hyperfine interaction is given as S.A.I. Thus, the interaction between the electron spin $S$ and the nuclear spin $I$ splits further each energy level of the electronic Zeeman interaction into $2 I+1$ levels corresponding to $2 I+1$ values of the magnetic quantum number $M_{\mathrm{I}}(-I,-I+1, \ldots, I-1, I)$. The allowed transition between two levels has to follow the selection rules in which $\Delta M_{\mathrm{S}}= \pm 1$ and $\Delta M_{\mathrm{I}}=0$. The forbidden transitions with $\Delta M_{\mathrm{I}}= \pm 1$ might become partly allowed in some particular cases $[94,95]$. For a spin center which has $S=1 / 2$ and a hyperfine interaction with an impurity having a nuclear spin $I=1 / 2$ and $100 \%$ natural abundance, the energy level will split into four levels under an external magnetic field $\mathbf{B}$. The hyperfine interaction is independent of the magnitude of $\mathbf{B}$ and occurs at zero field $(B=0)$, i.e. the energy 
level already splits off even for $B=0$ [Fig. 7(a)]. The dependence of these hyperfine-splitting levels on B [88] (pages 30-31) is shown in Fig. 7(a). In this EPR center, there are only two allowed transitions and, therefore, only two EPR lines can be observed (for the case of the electronic Zeeman and hyperfine interactions being isotropic) [Figs. 7].
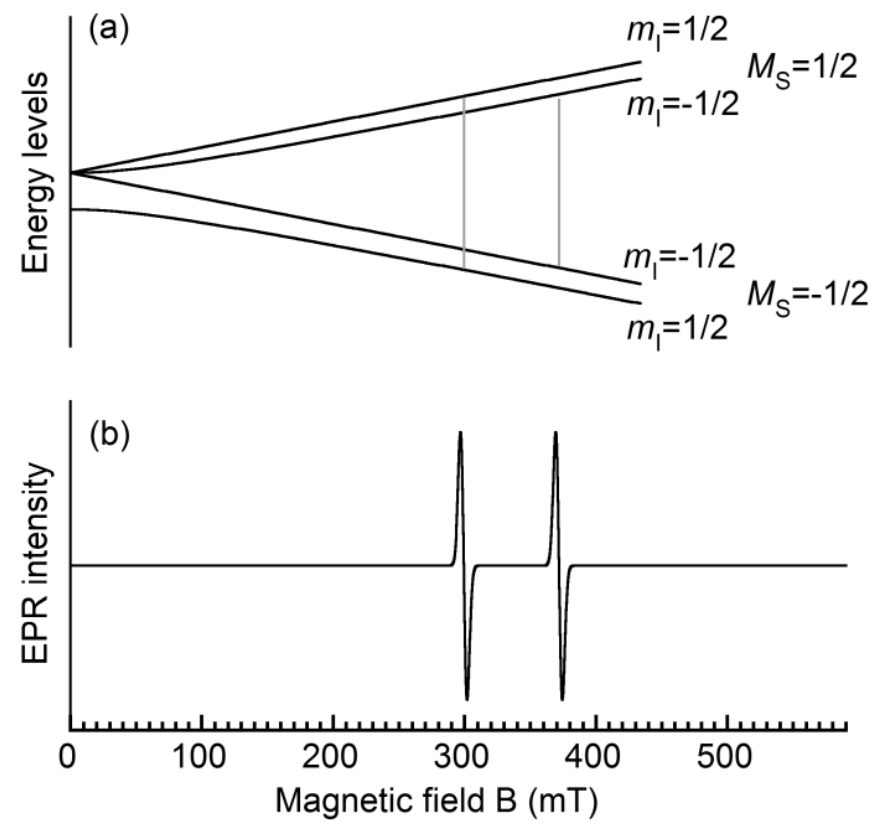

Figure 7. (a) The scheme of energy levels and (b) simulated EPR spectrum of an impurity with an electron spin $S=1 / 2$ and a nuclear spin $I=1 / 2$ (with $100 \%$ natural abundance). The vertical lines in figure (a) indicate the allowed transitions which give rise to the EPR lines observed in figure (b). For simulation, the electronic Zeeman and hyperfine interactions are isotropic $(g=2, A=2000 \mathrm{MHz})$ and the microwave frequency is $9.5 \mathrm{GHz}$.

In nature, many elements have several stable isotopes with different natural abundances and different nuclear spins and nuclear $g_{\mathrm{n}}$ factors. Thus, the hyperfine interactions involving these isotopes are different and can be distinguishable in the EPR spectrum. For an example, in $\mathrm{SiC}, \mathrm{Si}$ has three stable isotopes, ${ }^{28} \mathrm{Si}(I=0,92.2 \%$ natural abundance), ${ }^{29} \mathrm{Si}(I=1 / 2,4.7 \%$ natural abundance $)$ and ${ }^{30} \mathrm{Si}(I=0,3.1 \%$ natural abundance) while $\mathrm{C}$ has two isotopes, ${ }^{12} \mathrm{C}(I=0,98.9 \%$ natural abundance $)$ 
and ${ }^{13} \mathrm{C}(I=1 / 2,1.1 \%$ natural abundance). For carbon vacancies in $4 \mathrm{H}$ $\mathrm{SiC}[59,62]$, the hyperfine interactions between an electron spin $S=1 / 2$ and nuclear spins $I=1 / 2$ of ${ }^{29} \mathrm{Si}$ atoms occupying three nearest-neighbor sites in the basal plane can be equivalent. There is $\sim 86.55 \%$ $(\sim 95.3 \% \times 95.3 \% \times 95.3 \%)$ in probability that all three Si atoms has $I=0$ and, hence, no hyperfine interaction and only the Zeeman interaction responses for the observed EPR spectrum. There is $\sim 12.81 \%$ $(\sim 3 \times 4.7 \% \times 95.3 \% \times 95.3 \%)$ in probability that one of the three atoms is ${ }^{29} \mathrm{Si}$ and the hyperfine interaction gives rise to two hyperfine lines. The probabilities that two and three atoms among three $\mathrm{Si}$ in the basal plane are ${ }^{29} \mathrm{Si}$ are $\sim 0.63 \%(\sim 3 \times 4.7 \% \times 4.7 \% \times 95.3 \%)$ and $\sim 0.01 \%$ $(\sim 4.7 \% \times 4.7 \% \times 4.7 \%)$, respectively. The equivalent hyperfine interactions of $S=1 / 2$ and $I=1 / 2$ of two or three ${ }^{29} \mathrm{Si}$ atoms give rise to three (intensity ratio is $1: 2: 1$ ) or four (intensity ratio is $1: 3: 3: 1$ ) EPR lines,

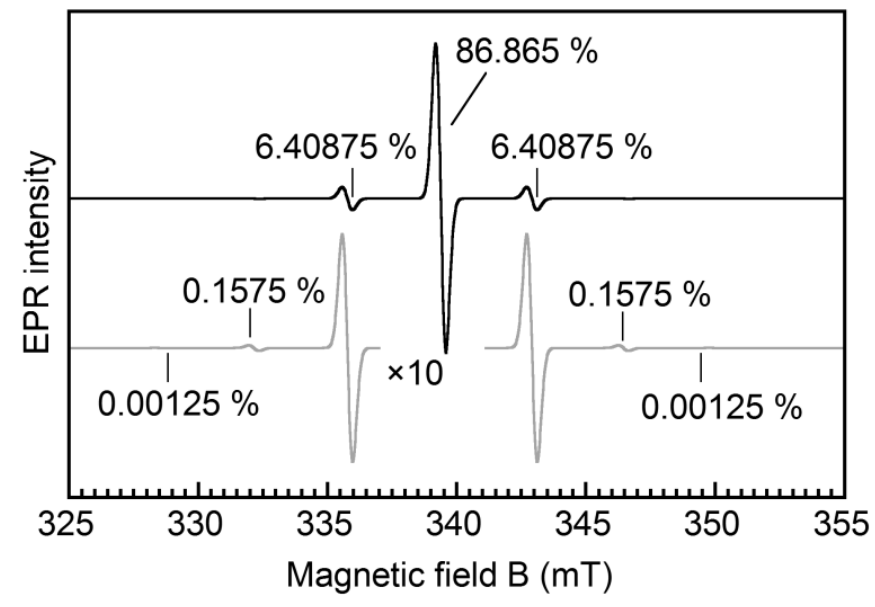

Figure 8. Simulated EPR spectrum of the carbon vacancy in SiC having electron spin $S=1 / 2$ and ligand hyperfine interaction with nuclear spins $I=1 / 2$ of ${ }^{29} \mathrm{Si}$ atoms occupying three equivalent sites in the basal plane The hyperfine lines of the observed EPR spectrum are shown in $\times 10$ intensity-scale spectrum. The two outer hyperfine pairs have small intensities and are often undetectable in EPR measurements. For simulation, the electronic Zeeman and hyperfine interactions are isotropic ( $g=2, A=200 \mathrm{MHz}$ ) and the microwave frequency is $9.5 \mathrm{GHz}$. 
respectively. Due to their small probabilities, the EPR lines related to hyperfine interactions of the electron spin $S=1 / 2$ and nuclear spins of two or three ${ }^{29} \mathrm{Si}$ occupying three equivalent sites in basal plane could not be observed in EPR spectrum [inset in Fig. 8]. The ratio of the intensity between the total intensity of the two strongest hyperfine lines in the inset of the Fig. 8 and the central line is calculated to be $\sim 14.76 \%$ $[\sim(12.81+3 / 4 * 0.01) /(86.55+0.63 / 2)]$. For $\mathrm{C}$, only the ${ }^{13} \mathrm{C}$ isotope has non-zero nuclear spin ( $I=1 / 2$ and $1.1 \%$ natural abundance), thus, the total intensity of its two hyperfine lines is $\sim 1.1 \%$ the intensity of the main line (for the case of hyperfine interaction with nuclear spin of ${ }^{13} \mathrm{C}$ occupying one site and the electronic Zeeman and hyperfine interactions being isotropic). From the number of hyperfine lines and the intensity ratio between hyperfine lines and the main line, we can determine the nuclear spin, the number of atoms involved in the hyperfine interaction and estimate the natural abundance of the isotopes, respectively. The information is very useful for identification of the involved atoms at the defect site and/or surrounding and, hence, the microscopic model of the defect.

\subsection{Spin-Hamiltonian and angular dependence}

The spin-Hamiltonian describing an electronic Zeeman interaction, spin-spin interaction and hyperfine interaction has the following form

$$
H=\mu_{\mathrm{B}} \text { B. g. } \mathbf{S}+\mathbf{S} . \mathbf{D} . \mathbf{S}+\sum_{i} \mathbf{S} . \mathbf{A}_{\mathbf{i}} \cdot \mathbf{I}_{\mathbf{i}} .
$$

Here, $\mathbf{g}, \mathbf{D}$ and $\mathbf{A}_{\mathbf{i}}$ are the tensors (usually symmetric tensors) describing the electronic Zeeman interaction, the spin-spin interaction and the hyperfine interaction, respectively. In the following sections, the physical principle of the angular dependence of EPR line positions caused by the anisotropy of these tensors is given.

\subsubsection{The $g$-tensor}

Generally, the $g$ factor of an unpaired electron at a point defect in a single crystal of solid is often not a constant but a tensor since the splitting of the energy levels by the external magnetic field at different crystal directions can be anisotropic. The anisotropy of the $g$ factor can be explained by the anisotropy of local magnetic field [86] (pages 23-27). The calculation of the $g$ factor and its anisotropic property is 
available [96-98] and it could be used to identify the origin of the unpaired electron center.

In a single crystal, there are equivalent orientations and one defect is expected to exist in all orientations with a similar probability. For a low symmetry $g$-tensor and at an arbitrary direction of $\mathbf{B}$, these different orientations of the defect can have different effective values of $g$. The inequivalent effective values of $g$ result in different magnetic field positions of EPR lines.

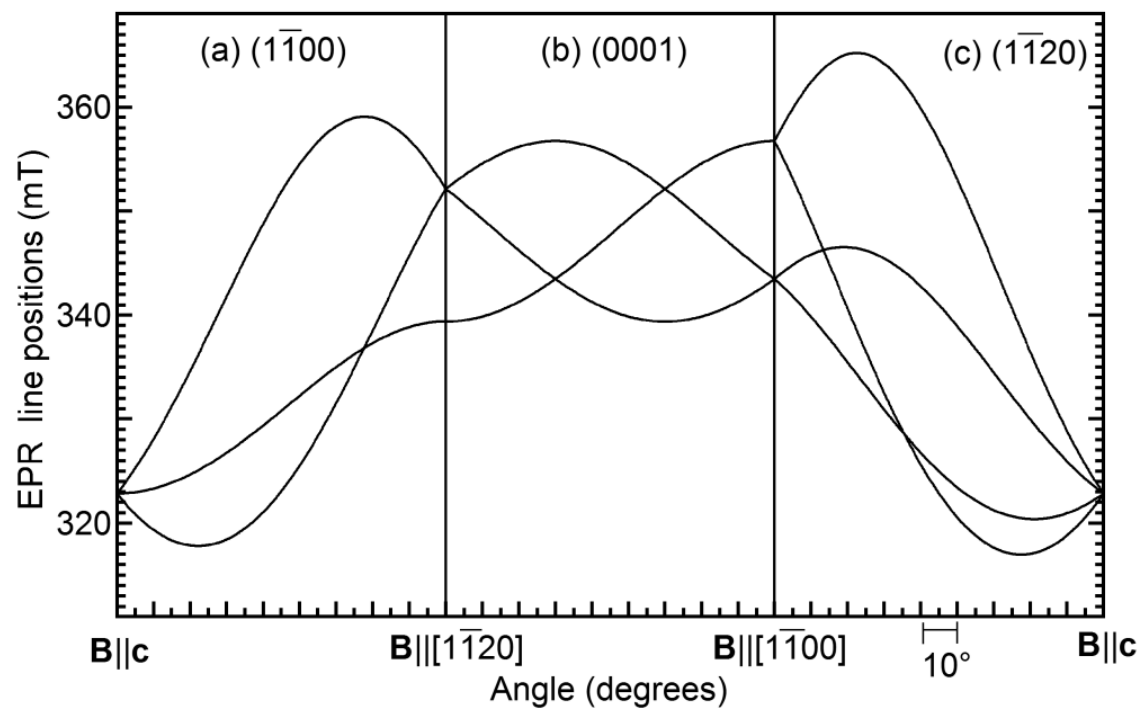

Figure 9. Simulated angular dependence of EPR line positions of spin a center with $C_{1 \mathrm{~h}}$ symmetry $g$-tensor in a single crystal with hexagonal lattice when the magnetic field rotates in (a) (1 $\overline{1}$ 00) (b) (0001) and (c) $(11 \overline{2} 0)$ planes. The symmetric $g$-tensor used for simulation has components $g_{\mathrm{xx}}=2, g_{\mathrm{xy}}=g_{\mathrm{xz}}=0, g_{\mathrm{yy}}=1.9, g_{\mathrm{yz}}=0.1, g_{\mathrm{zz}}=2.1$ (the axes $\mathrm{x}, \mathrm{y}, \mathrm{z}$ are parallel to [11 $\overline{2} 0],[1 \overline{1} 00]$ and $c$-directions, respectively) and the frequency of microwave is $9.5 \mathrm{GHz}$.

The number of EPR splitting lines is determined by the symmetry of both the crystal lattice and the $g$-tensor of the defect. In the hexagonal lattice such as $4 \mathrm{H}-\mathrm{SiC}, 6 \mathrm{H}-\mathrm{SiC}$ and wurtzite III-nitrides, there are six possible orientations of a defect having the same angle $\theta$ (the angle between the $c$-axis and the orientation of the defect) but with $\varphi$ differing from each other by $60^{\circ}(\varphi$ is the angle between the [11 $\overline{2} 0]$ direction and 
the projection of the orientation of the defect on the (0001) plane). When $\mathbf{B} \| \mathbf{c}$, the six possible orientations of the defect are equivalent and their six EPR lines coincide, giving rise to a single EPR line with six times in intensity. At an arbitrary direction of the magnetic field, the line splits into six lines if the $g$-tensor has $C_{1}$ symmetry. For higher symmetry of the $g$-tensor, some orientations of the defect become equivalent, giving rise to the same effective values of $g$ and, thus, reducing the number of observed EPR lines and increasing the intensity of the coincident lines. If the $g$-tensor has $C_{1 \mathrm{~h}}$ symmetry in which the principal vector $\mathbf{g}_{X}$ of the $g$-tensor is parallel to the crystal axis [11 $\left.\overline{2} 0\right]$, the values of $\varphi$ of six possible orientations of the defect are $\varphi_{1}=0^{\circ}, \varphi_{2}=60^{\circ}$, $\varphi_{3}=120^{\circ}, \varphi_{4}=180^{\circ}, \varphi_{5}=240^{\circ}$ and $\varphi_{6}=300^{\circ}$. When rotating the magnetic field in the $(1 \overline{1} 00)$, the first orientation $\left(\varphi_{1}=0^{\circ}\right)$ becomes equivalent with the fourth orientation $\left(\varphi_{3}=180^{\circ}\right)$, the second orientation $\left(\varphi_{2}=60^{\circ}\right)$ becomes equivalent with the third orientation $\left(\varphi_{3}=120^{\circ}\right)$ and the fifth orientation $\left(\varphi_{5}=240^{\circ}\right)$ becomes equivalent with the sixth orientation $\left(\varphi_{6}=300^{\circ}\right)$ of the defect. Therefore, there will be 3 distinguished EPR lines (intensity ratio is 2:2:2) (Fig. 9). When rotating the magnetic field in the $(11 \overline{2} 0)$, the second orientation becomes equivalent with the sixth orientation, the third orientation becomes equivalent with the fifth orientation of the defect while the first and the fourth orientation are inequivalent. Therefore, there will be 4 distinguished EPR lines (intensity ratio is $1: 2: 2: 1)$ when rotating the magnetic field in the (11 $\overline{2} 0)$ (Fig. 9). In the case of $C_{3 \mathrm{v}}$ symmetry, the principal vector of the $g$-tensor is parallel to the $c$-axis and $g_{\mathrm{X}}=g_{\mathrm{Y}}$, so all six possible orientations of the defect become equivalent and corresponding EPR lines coincide. In EPR experiments, the $g$-tensor of the defect can be determined from the leastsquare fits of the obtained angular dependence using the first term of Eq. (7) with the magnetic field rotating in a high symmetric plane, such as $(11 \overline{2} 0)$ or $(1 \overline{1} 00)$ or equivalent planes.

\subsubsection{The $D$-tensor}

The spin-spin interaction is described by the $D$-tensor which is a second-rank traceless tensor with the sum of the three principal values $D_{\mathrm{X}}$, $D_{\mathrm{Y}}, D_{\mathrm{Z}}$ being zero. Conventionally, the assignment of three principal values is based on the following order $\left|D_{Z}\right|>\left|D_{Y}\right|>\left|D_{X}\right|$. Since $D_{\mathrm{X}}+D_{\mathrm{Y}}+D_{\mathrm{Z}}=0$, we often use two parameters $D$ and $E$ to describe the 
principal values of the tensor in which $D_{\mathrm{Z}}=2 D / 3, D_{\mathrm{X}}=-D / 3+E$ and $D_{\mathrm{Y}}=-$ $D / 3-E$.

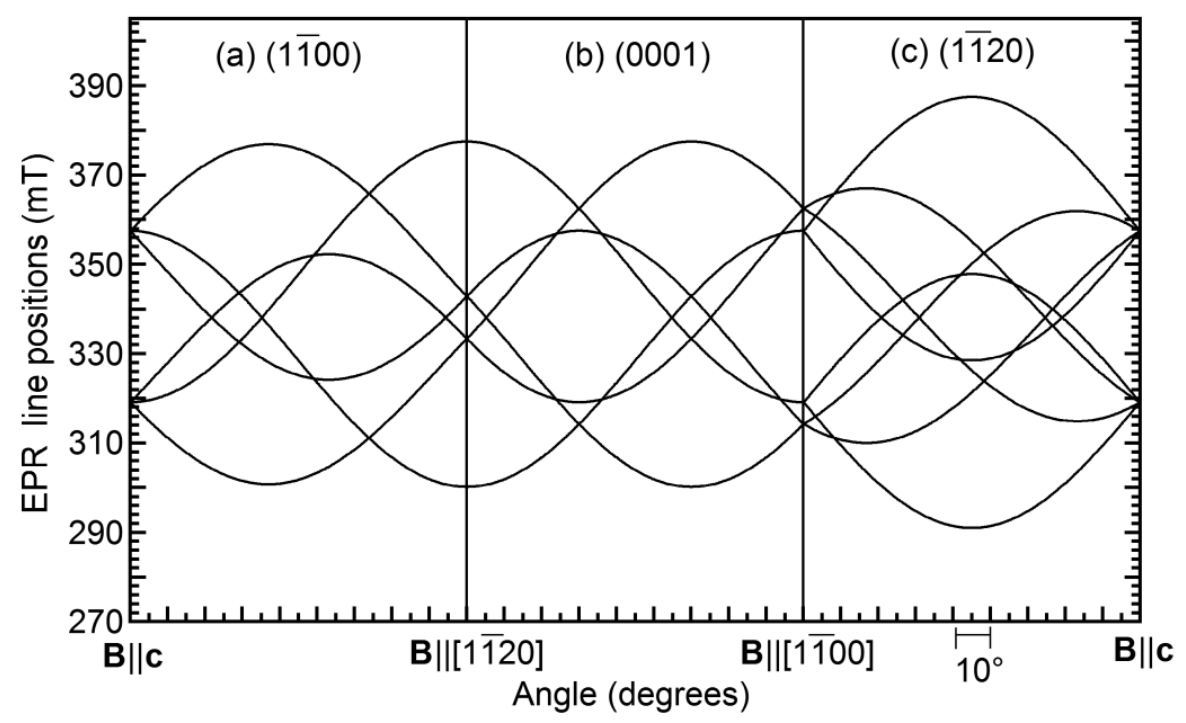

Figure 10. Simulated angular dependence of EPR line positions of a spin center with $S=1$ in a single crystal with the hexagonal lattice when the magnetic field rotates in (a) $(1 \overline{1} 00)$ (b) $(0001)$ and (c) $(11 \overline{2} 0)$ planes. For the simulation, the $g$-tensor is isotropic $(g=2)$, the symmetric $D$-tensor has components $D_{\mathrm{xx}}=-720 \mathrm{MHz}, D_{\mathrm{yy}}=D_{\mathrm{zz}}=360 \mathrm{MHz}$, $D_{\mathrm{yz}}=540 \mathrm{MHz}, D_{\mathrm{xy}}=D_{\mathrm{xz}}=0$, (the axes x, y, z are parallel to [11 $\left.\overline{2} 0\right]$, [1 $\overline{1}$ $00]$ and $c$-directions, respectively) and the frequency of microwave is $9.5 \mathrm{GHz}$.

The number of EPR splitting lines is determined by the symmetry of $g$ - and $D$-tensors. The angular dependence of EPR lines position of a spin center having $S=1$, isotropic $g$-tensor and $C_{1 \mathrm{~h}}$ symmetry of $D$-tensor lines when rotating the magnetic field in the $(1 \overline{1} 00),(0001)$ and $(11 \overline{2} 0)$ planes is shown in Fig. 10. In EPR experiment, the $g$ - and $D$-tensors of the defect can be determined from the least-square fits of the obtained angular dependence using the first term and the second term of Eq. (7) with the magnetic field rotating in a high symmetric plane, such as (11 $\overline{2} 0)$ or $(1 \overline{1} 00)$ or equivalent planes.

\subsubsection{The $A$-tensor}


In solid crystals, the hyperfine interaction is often anisotropic and described by the $A$-tensor. The symmetry of the $A$-tensor can be lower than that of the $g$-tensor and, therefore, the number of the hyperfine lines can be more than expected for the electronic Zeeman interaction (Fig. 11). From analysis of the angular dependence of the EPR line positions with the magnetic field $\mathbf{B}$ rotating in a certain high symmetric plane using Eq. (7), the hyperfine $A$-tensor can be determined. From the obtained hyperfine data, possible defect models can be suggested and compared to the corresponding values obtained from theoretical calcula-

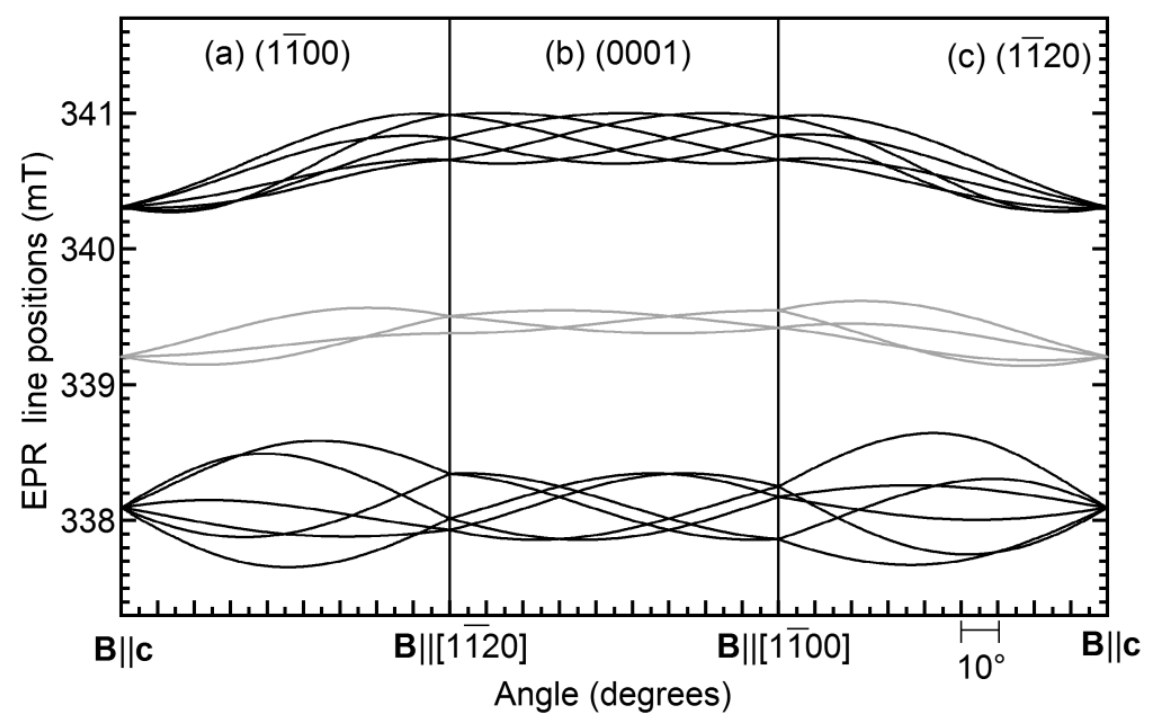

Figure 11. Simulated angular dependence of EPR line positions (upper and lower lines) of a spin center with $S=1 / 2$ having a hyperfine interaction with a nuclear spin $I=1 / 2$ in a single crystal with the hexagonal lattice when the magnetic field rotates in (a) $(1 \overline{1} 00)$ (b) (0001) and (c) $(11 \overline{2} 0)$ planes. For the simulation, the symmetric $g$-tensor has components $g_{\mathrm{xx}}=2, g_{\mathrm{yy}}=1.999, g_{\mathrm{zz}}=2.001, g_{\mathrm{yz}}=0.001, g_{\mathrm{xy}}=g_{\mathrm{xz}}=0\left(C_{1 \mathrm{~h}}\right.$ symmetry), the symmetric $A$-tensor has components $A_{\mathrm{xx}}=-80 \mathrm{MHz}, A_{\mathrm{yy}}=70$ $\mathrm{MHz}, A_{\mathrm{zz}}=60 \mathrm{MHz}, A_{\mathrm{xy}}=10 \mathrm{MHz}, A_{\mathrm{xz}}=5, A_{\mathrm{yz}}=15 \mathrm{MHz}$ ( $C_{1}$ symmetry) (the axes $\mathrm{x}, \mathrm{y}, \mathrm{z}$ are parallel to [11 $\overline{2} 0],[1 \overline{1} 00]$ and $c$-directions, respectively) and the frequency of microwave is $9.5 \mathrm{GHz}$. 
tions. The correlation between EPR experiments and theoretical calculations allows a conclusive identification of the defect.

In semiconductors, intrinsic defects or impurities have strong influence on the properties of the materials. The obtained $g$-tensor provides information about the symmetry of the defect. If the impurities have a nuclear spin $I \neq 0$, the involved impurities can be directly and chemically identified from the observed self-hyperfine structure. The information on neighboring atoms of a defect or an impurity can be obtained from the ligand-hyperfine structure. Such information is essential for identification of the defect and understanding its electronic structure. In many cases, identification of point defects in semiconductors needs additional help from theoretical modeling of the defect. 


\section{References}

[1] W. A. M. Hijnen, E. F. Beerendonk, and G. J. Medema, Water Res. 40, 3 (2006).

[2] S. Vilhunen, H. Särkkä, and M. Sillanpää, Environ. Sci. Pollut. Res. 16, 439 (2009).

[3] M. A. Würtele, T. Kolbe, M. Lipsz, A. Külberg, M. Weyers, M. Kneissl, and M. Jekel, Water Res. 45, 1481 (2011).

[4] H. Morkoç, S. Strite, G. B. Gao, M. E. Lin, B. Sverdlov, and M. Burns, J. Appl. Phys. 76, 1363 (1994).

[5] S. Nakamura, T. Mukai, and M. Senoh, Jpn. J. Appl. Phys. 30, L1998 (1991).

[6] Y. Taniyasu, M. Kasu, and T. Makimoto, Nature 441, 325 (2006).

[7] A. Khan, K. Balakrishnan, and T. Katona, Nat. Photonics 2, 77 (2008).

[8] Z. Lochner, T.-T. Kao, Y.-S. Liu, X.-H. Li, M. Mahbub Satter, S.C. Shen, P. Douglas Yoder, J.-H. Ryou, R. D. Dupuis, Y. Wei, H. Xie, A. Fischer, and F. A. Ponce, Appl. Phys. Lett. 102, 101110 (2013).

[9] M. L. Nakarmi, K. H. Kim, K. Zhu, J. Y. Lin, and H. X. Jiang, Appl. Phys. Lett. 85, 3769 (2004).

[10] R. Collazo, S. Mita, J. Xie, A. Rice, J. Tweedie, R. Dalmau, and Z. Sitar, Phys. Status Solidi C 8, 2031 (2011).

[11] F. Mehnke, T. Wernicke, H. Pingel, C. Kuhn, C. Reich, V. Kueller, A. Knauer, M. Lapeyrade, M. Weyers, and M. Kneissl, Appl. Phys. Lett. 103, 212109 (2013).

[12] Y. Taniyasu, M. Kasu, and N. Kobayashi, Appl. Phys. Lett. 81, 1255 (2002).

[13] K. Zhu, M. L. Nakarmi, K. H. Kim, J. Y. Lin, and H. X. Jiang, Appl. Phys. Lett. 85, 4669 (2004).

[14] G. M. Prinz, M. Feneberg, M. Schirra, R. Sauer, K. Thonke, S. B. Thapa, and F. Scholz, Phys. Status Solidi -RRL 2, 215 (2008).

[15] A. Kakanakova-Georgieva, D. Nilsson, X. T. Trinh, U. Forsberg, N. T. Son, and E. Janzén, Appl. Phys. Lett. 102, 132113 (2013).

[16] C. H. Park and D. J. Chadi, Phys. Rev. B 55, 12995 (1997).

[17] P. Bogusławski and J. Bernholc, Phys. Rev. B 56, 9496 (1997).

[18] C. G. Van De Walle, Phys. Rev. B 57, R2033 (1998). 
[19] M. D. McCluskey, N. M. Johnson, C. G. Van de Walle, D. P. Bour, M. Kneissl, and W. Walukiewicz, Phys. Rev. Lett. 80, 4008 (1998).

[20] J.-M. Mäki, I. Makkonen, F. Tuomisto, A. Karjalainen, S. Suihkonen, J. Räisänen, T. Y. Chemekova, and Y. N. Makarov, Phys. Rev. B 84, R081204 (2011).

[21] A. Sedhain, J. Y. Lin, and H. X. Jiang, Appl. Phys. Lett. 100, 221107 (2012).

[22] A. F. Wright, J. Appl. Phys. 92, 2575 (2002).

[23] J. L. Lyons, A. Janotti, and C. G. Van De Walle, Phys. Rev. B 89, 035204 (2014).

[24] K. Irmscher, C. Hartmann, C. Guguschev, M. Pietsch, J. Wollweber, and M. Bickermann, J. Appl. Phys. 114, 123505 (2013).

[25] C. G. Van De Walle and J. Neugebauer, J. Appl. Phys. 95, 3851 (2004).

[26] P. W. Anderson, Phys. Rev. Lett. 34, 953 (1975).

[27] X. T. Trinh, D. Nilsson, I. G. Ivanov, E. Janzén, A. KakanakovaGeorgieva, and N. T. Son, Appl. Phys. Lett. 103, 042101 (2013).

[28] X. T. Trinh, D. Nilsson, I. G. Ivanov, E. Janzén, A. KakanakovaGeorgieva, and N. T. Son, Appl. Phys. Lett. 105, 162106 (2014).

[29] D. V. Lang and R. A. Logan, Phys. Rev. Lett. 39, 635 (1977).

[30] D. V. Lang, R. A. Logan, and M. Jaros, Phys. Rev. B 19, 1015 (1979).

[31] X. Liu, L. Samuelson, M.-E. Pistol, M. Gerling, and S. Nilsson, Phys. Rev. B 42, 11791 (1990).

[32] D. J. Chadi and K. J. Chang, Phys. Rev. Lett. 61, 873 (1988).

[33] T. Kinato and M. Mizuta, Jpn. J. Appl. Phys. 26, L1806 (1987).

[34] M. Mizuta and T. Kitano, Appl. Phys. Lett. 52, 126 (1988).

[35] K. M. Yu, K. Khachaturyan, E. R. Weber, H. P. Lee, and E. G. Colas, Phys. Rev. B 43, R2462 (1991).

[36] R. E. Peale, H. Sun, and G. D. Watkins, Phys. Rev. B 45, 3353 (1992).

[37] D. J. Chadi, Phys. Rev. B 46, 6777 (1992).

[38] R. E. Peale, Y. Mochizuki, H. Sun, and G. D. Watkins, Phys. Rev. B 45, 5933 (1992).

[39] H. J. von Bardeleben, I. Buyanova, A. Belyaev, and M. Sheinkman, Phys. Rev. B 45, 11667 (1992). 
[40] P. M. Mooney, T. N. Theis, and E. Calleja, J. Electron. Mater. 20, 23 (1991).

[41] F. Rziga Ouaja, H. Mejri, A. Selmi, and P. Gibart, J. Appl. Phys. 82, 5509 (1997).

[42] A. Triki, F. Rziga-Ouaja, H. Mejri, and A. Selmi, J. Appl. Phys. 93, 9769 (2003).

[43] J. Ma and S.-H. Wei, Phys. Rev. B 87, 115210 (2013).

[44] J. S. Blackemore, Semiconductors Statistics (Pergamon Press Inc., London, 1962), p. 142 and 161.

[45] D. Adler and E. J. Yoffa, Phys. Rev. Lett. 36, 1197 (1976).

[46] N. W. Ashcroft and N. D. Mermin, Solid State Physics (Thomson Learning, London, 1976), p. 581.

[47] D. C. Look, Phys. Rev. B 24, 5852 (1981).

[48] A. Kakanakova-Georgieva, D. Nilsson, M. Stattin, U. Forsberg, Å. Haglund, A. Larsson, and E. Janzén, Phys. Status Solidi -RRL 4, 311 (2010).

[49] A. Kakanakova-Georgieva, P. O. A. Persson, A. Kasic, L. Hultman, and E. Janzén, J. Appl. Phys. 100, 036105 (2006).

[50] S. E. Saddow and A. Agarwal, editors , Advances in SiC Processing and Applications (Artech House, Boston, 2004).

[51] J. A. Lely, Berichte Der Dtsch. Keramischen Gesellshaft 32, 229 (1955).

[52] Y. M. Tairov and V. F. Tsvetkov, J. Cryst. Growth 43, 209 (1978).

[53] H. Matsunami, S. Nishino, and H. Ono, IEEE Trans. Electron Devices 28, 1235 (1981).

[54] H. Matsunami and T. Kimoto, Mater. Sci. Eng. R 20, 125 (1997).

[55] W. J. Choyke, D. R. Hamilton, and L. Patrick, Phys. Rev. 133, A1163 (1964).

[56] Y. Matsushita, S. Furuya, and A. Oshiyama, Phys. Rev. Lett. 108, 246404 (2012).

[57] Y. Matsushita and A. Oshiyama, Phys. Rev. Lett. 112, 136403 (2014).

[58] S. Greulich-Weber, Phys. Stat. Sol. A 162, 95 (1997).

[59] T. Umeda, J. Isoya, N. Morishita, T. Ohshima, T. Kamiya, A. Gali, P. Deák, N. T. Son, and E. Janzén, Phys. Rev. B 70, 235212 (2004). 
[60] T. Umeda, Y. Ishitsuka, J. Isoya, N. T. Son, E. Janzén, N. Morishita, T. Ohshima, H. Itoh, and A. Gali, Phys. Rev. B 71, 193202 (2005).

[61] N. T. Son, X. T. Trinh, L. S. Løvlie, B. G. Svensson, K. Kawahara, J. Suda, T. Kimoto, T. Umeda, J. Isoya, T. Makino, T. Ohshima, and E. Janzén, Phys. Rev. Lett. 109, 187603 (2012).

[62] X. T. Trinh, K. Szász, T. Hornos, K. Kawahara, J. Suda, T. Kimoto, A. Gali, E. Janzén, and N. T. Son, Phys. Rev. B 88, 235209 (2013).

[63] A. Elasser and T. P. Chow, Proc. IEEE 90, 969 (2002).

[64] J. A. Cooper and A. Agarwal, Proc. IEEE 90, 956 (2002).

[65] V. A. Vashchenko and A. Shibkov, ESD Design for Analog Circuits, Chapter 2 (Springer US, Boston, MA, 2010).

[66] P. B. Klein, J. Appl. Phys. 103, 033702 (2008).

[67] H. Lendenmann, F. Dahlquist, J. P. Bergman, H. Bleichner, and C. Hallin, Mater. Sci. Forum 389-393, 1259 (2002).

[68] Y. Sugawara, D. Takayama, K. Asano, A. Agarwal, S. Ryu, J. Palmour, and A. Ogata, Proc. Int. Symp. Power Semicond. Devices ICs, 365 (2004).

[69] T. Hiyoshi and T. Kimoto, Appl. Phys. Express 2, 041101 (2009).

[70] R. N. Hall, Phys. Rev. 87, 387 (1952).

[71] W. Shockley and W. T. Read, Phys. Rev. 87, 835 (1952).

[72] T. Kimoto, K. Danno, and J. Suda, Phys. Status Solidi B 245, 1327 (2008).

[73] T. Hiyoshi and T. Kimoto, Appl. Phys. Express 2, 091101 (2009).

[74] P. B. Klein, B. V. Shanabrook, S. W. Huh, A. Y. Polyakov, M. Skowronski, J. J. Sumakeris, and M. J. O’Loughlin, Appl. Phys. Lett. 88, 052110 (2006).

[75] T. Kimoto, T. Hiyoshi, T. Hayashi, and J. Suda, J. Appl. Phys. 108, (2010).

[76] J. Zhang, L. Storasta, J. P. Bergman, N. T. Son, and E. Janzén, J. Appl. Phys. 93, 4708 (2003).

[77] T. Tawara, H. Tsuchida, S. Izumi, I. Kamata, and K. Izumi, Mater. Sci. Forum 457-460, 565 (2004).

[78] K. Danno, D. Nakamura, and T. Kimoto, Appl. Phys. Lett. 90, 202109 (2007).

[79] T. Dalibor, G. Pensl, H. Matsunami, T. Kimoto, W. J. Choyke, A. Schöner, and N. Nordell, Phys. Status Solidi A 162, 199 (1997). 
[80] T. Kimoto, A. Itoh, H. Matsunami, S. Sridhara, L. L. Clemen, R. P. Devaty, W. J. Choyke, T. Dalibor, C. Peppermüller, and G. Pensl, Appl. Phys. Lett. 67, 2833 (1995).

[81] L. Storasta and H. Tsuchida, Appl. Phys. Lett. 90, 062116 (2007).

[82] T. Miyazawa, M. Ito, and H. Tsuchida, Appl. Phys. Lett. 97, 202106 (2010).

[83] S. Ichikawa, K. Kawahara, J. Suda, and T. Kimoto, Appl. Phys. Express 5, 101301 (2012).

[84] E. K. Zavoisky, Ph.D. Thesis 1944; J. Phys. USSR 9,221 and 245 (1945); and ibid 10, 197 (1946).

[85] N. F. Ramsey, Bull. Magn. Reson. 7, 94 (1985).

[86] J. A. Well and J. R. Bolton, Electron Paramagnetic Resonance: Elementary Theory and Practical Applications, Second Edi (John Wiley \& Sons, Inc, Hoboken, New Jersey, 2007).

[87] P. Zeeman, Nature 55, 347 (1897).

[88] J. Charles P. Poole and H. A. Farach, Theory of Magnetic Resonance, Second Edi (John Wiley \& Sons, Inc, New York, 1987).

[89] B. Odom, D. Hanneke, B. D’Urso, and G. Gabrielse, Phys. Rev. Lett. 97, 030801 (2006).

[90] J. Schwinger, Phys. Rev. 73, 416L (1948).

[91] www.bruker.com.

[92] M. Bennati and D. M. Murphy, in Electron Paramagn. Reson. A Pract. Toolkit, edited by M. Brustolon and E. Giamello (John Wiley \& Sons, Inc, Hoboken New Jersey, 2009), p. 234.

[93] E. Malguth, a. Hoffmann, W. Gehlhoff, O. Gelhausen, M. Phillips, and X. Xu, Phys. Rev. B 74, 165202 (2006).

[94] N. T. Son, A. Henry, J. Isoya, M. Katagiri, T. Umeda, A. Gali, and E. Janzén, Phys. Rev. B 73, 075201 (2006).

[95] P. Carlsson, N. T. Son, A. Gali, J. Isoya, N. Morishita, T. Ohshima, B. Magnusson, and E. Janzén, Phys. Rev. B 82, 235203 (2010).

[96] C. J. Pickard and F. Mauri, Phys. Rev. Lett. 88, 086403 (2002).

[97] F. Pietrucci, M. Bernasconi, C. Di Valentin, F. Mauri, and C. Pickard, Phys. Rev. B 73, 134112 (2006).

[98] C. Freysoldt, B. Grabowski, T. Hickel, J. Neugebauer, G. Kresse, A. Janotti, and C. G. Van De Walle, Rev. Mod. Phys. 86, 253 (2014). 


\section{Part II. Papers}




\section{Summary of the papers}

\section{Paper 1}

We showed that $\mathrm{Si}$ already forms a stable DX center in $\mathrm{Al}_{\mathrm{x}} \mathrm{Ga}_{1-\mathrm{x}} \mathrm{N}$ with $\mathrm{x} \sim 0.77$. However, with the Fermi level locating only $\sim 3 \mathrm{meV}$ below $\mathrm{E}_{\mathrm{d}}$, Si still behaves as a shallow donor and high conductivity at room temperature could be achieved in $\mathrm{Al}_{0.77} \mathrm{Ga}_{0.23} \mathrm{~N}$ :Si layers. In samples with the concentration of the residual oxygen $(\mathrm{O})$ impurity larger than that of $\mathrm{Si}$, we observed no carrier compensation by $\mathrm{O}$ in $\mathrm{Al}_{0.77} \mathrm{Ga}_{0.23} \mathrm{~N}: \mathrm{Si}$ layers, suggesting that at such $\mathrm{Al}$ content, $\mathrm{O}$ does not seem to hinder the $n$-type doping in the material.

\section{Paper 2}

We determined the dependence of the $\mathrm{E}_{\mathrm{DX}}$ level of $\mathrm{Si}$ on the $\mathrm{Al}$ content in $\mathrm{Al}_{\mathrm{x}} \mathrm{Ga}_{1-\mathrm{x}} \mathrm{N}$ : $\mathrm{Si}$ layers $(0.79 \leq \mathrm{x} \leq 1)$ with the $\mathrm{Si}$ concentration of $\sim 2 \times 10^{18}$ $\mathrm{cm}^{-3}$ and the concentrations of residual $\mathrm{O}$ and $\mathrm{C}$ impurities of about an order of magnitude lower $\left(\sim 1 \div 2 \times 10^{17} \mathrm{~cm}^{-3}\right)$. We found the coexistence of two DX centers (stable and metastable ones) of $\mathrm{Si}$ in $\mathrm{Al}_{\mathrm{x}} \mathrm{Ga}_{1-\mathrm{x}} \mathrm{N}$ for $x \geq 0.84$. For the stable DX center, abruptly deepening of $E_{D X}$ with increasing of the $\mathrm{Al}$ content for $\mathrm{x} \geq 0.83$ was observed, explaining the drastic decrease of the conductivity as often reported in previous transport studies. For the metastable DX center, the $\mathrm{E}_{\mathrm{DX}}$ level remains close to $\mathrm{E}_{\mathrm{d}}$ for $\mathrm{x}=0.84 \div 1(\sim 11 \mathrm{meV}$ for $\mathrm{AlN})$.

\section{Paper 3}

The identification of niobium $(\mathrm{Nb})$ in $4 \mathrm{H}-$ and $6 \mathrm{H}-\mathrm{SiC}$ grown by hightemperature chemical vapor deposition (CVD) by EPR and theoretical calculations is presented. We showed that the incorporated $\mathrm{Nb}$ formed asymmetric split-vacancy defect $\left(\mathrm{Nb}_{\mathrm{Si}} \mathrm{V}_{\mathrm{C}}\right)$ in which $\mathrm{Nb}$ locates in a divacancy, closer to the Si vacancy, and prefers only the hexagonalhexagonal configuration.

\section{Paper 4}

Using EPR, photo-EPR, DLTS and capacitance-voltage measurements, we showed that the $Z_{1} / Z_{2}$ center is related to the (2-|0) level of $V_{C}$ and 
its higher-lying levels $Z_{1}$ and $Z_{2}$ are related to the (-|0) levels of $V_{C}$ at the hexagonal $(h)$ and quasi-cubic $(k)$ sites, respectively.

\section{Paper 5}

Combining EPR and supercell calculations, the negatively charged $\mathrm{V}_{\mathrm{C}}$ at the $k$-site was identified. We obtained the excellent agreement in the energy levels of $Z_{1} / Z_{2}$ determined by DLTS and energy levels of $V_{C}$ calculated by supercell calculations and observed clear negative-U behaviors of the negatively charged $\mathrm{V}_{\mathrm{C}}$ at both $k$ and $h$-sites by EPR measurements, consolidating our assignment of the $Z_{1} / Z_{2}$ levels to the negatively charged states of $\mathrm{V}_{\mathrm{C}}$.

\section{Paper 6}

We observed an EPR center, named as EI8, at room temperature in irradiated layers. The center has two configurations in which the EI8a configuration was converted to the EI8b configuration after a short annealing at temperatures in the range of $300-500{ }^{\circ} \mathrm{C}$ in darkness and the EI8b configuration was converted back to the EI8a configuration under illumination at room temperature. Based on the observed ${ }^{29} \mathrm{Si}$ and ${ }^{13} \mathrm{C}$ hyperfine structures, two configurations of the EPR center were suggested to be related different configurations of a carbon interstitial cluster. The annealing, metastable behaviors and energy levels of this EPR center are discussed. 


\section{Papers}

The articles associated with this thesis have been removed for copyright reasons. For more details about these see:

http://urn.kb.se/resolve?urn=urn:nbn:se:liu:diva-117882 